\title{
FIRM FINANCING IN CHILE AFTER THE 2014-2015 TAX REFORM: DEBT OF EQUITY?
}

FINANCIAMIENTO CORPORATIVO EN CHILE LUEGO DE LA REFORMA TRIBUTARIA 2014-2015: ¿DEUDA O CAPITAL?

\section{LEONARDO HERNANDEZ T.*}

The World Bank

\begin{abstract}
This paper analyzes the effects of the 2014-2015 Chilean tax reform on firms' valuation and incentives to retain earnings and finance their operations with equity versus debt. By analyzing the effects of the reform on total taxes paid and cash flows received by investors, the paper concludes that in general the reform reduces the value of firms and lessens the incentives to retain earnings. Also, simulations show that the majority of firms would choose the accrual or 'attributed' tax based system. However, if the latter is not permitted firms will choose debt over equity. The cash-based or semi-integrated system becomes the preferred option only when tax avoidance is possible.
\end{abstract}

Keywords: Corporate tax, income tax, payout ratio, tax avoidance, firm financing.

JEL Classification: D92, G32, G35, H24, H26.

\section{Resumen}

Este trabajo estudia los efectos de la reforma tributaria 2014-2015 en Chile sobre el valor económico de las firmas y los incentivos a retener utilidades y financiar sus operaciones con patrimonio versus deuda. Al analizar los efectos de la reforma sobre los impuestos pagados y los flujos de caja de los inversionistas se concluye que, en general, la reforma disminuye el valor económico de las firmas y los incentivos a retener utilidades. Además, la

* E-mail: fhernandez@worldbank.org. This article reflects the author's views and not those of the World Bank, its member countries or its Board of Directors. 
mayoría de las empresas optarían por el sistema atribuido -o por deuda cuando este no es posible. El sistema semiintegrado resulta atractivo solo bajo elusión.

Palabras clave: Impuestos corporativos, impuesto a la renta, dividendos, elusión, financiamiento corporativo.

Clasificación JEL: D92, G32, G35, H24, H26.

\section{INTRODUCTION}

The tax reform approved in September of 2014 in Chile (Law 20.780), which is to be implemented in stages until $2017^{1}$, increased the corporate tax rate from 20 to either 25 or $27 \%$, reduced the top personal income tax rate from 40 to $35 \%$ and, among other measures ${ }^{2}$, introduced two alternatives for shareholders to comply with their personal income tax obligations, namely: (a) an accrual-based (or 'attributed') regime in which all earnings are taxable when generated, irrespective of whether they are distributed or retained by the firm, and (b) a cash-based (or semi-integrated) regime in which only distributed dividends are taxable. A subsequent amendment to the reform in early 2016 (Law 20.899), aimed at simplifying the tax code, reduced firms' possibilities to choose between options (a) and (b) above. In particular, the accrual-based system was ruled out for firms which are not owned exclusively by individuals - companies which count with at least one firm among their shareholders must use the semi-integrated tax regime.

This article analyses both alternative tax regimes from the shareholders' point of view, with the aim of better understanding the choice they need to make between both regimes in the second half of 2016, before the new law becomes fully in effect. Based on such analysis the article sheds some light on the effects of the new tax law on firms' economic value vis-à-vis the situation pre-reform. The article, an extension and update of a previous paper after the recent amendment to the reform (see Hernández, 2015), also analyses the possible effects of the tax reform on firms' decision to finance their operations with debt as opposed to equity.

The next section describes the tax system prevailing previous to the reform and those after the reform: the accrual-based system (alternative 1) and the cash-based system (alternative 2). The analysis, carried through a hypothetical example, compares the cash flows received and taxes paid by investors under equity- and debt-financing for all systems. Next, Section 3 generalizes the results of Section 2 and carries the

1 The new tax code will fully apply to all income generated in 2017 (taxes due in April of 2018), except for the corporate tax rate under the cash-based or semi-integrated regime that will increase from 25.5 to $27 \%$ in 2018 .

2 For detailed information on the tax reform see Katsz, 2014; Libray of Congress, Chile, 2014; Ministry of Finance, Chile, 2014a and 2014b; and Vidaurre, 2014. For a description of other measures under the reform see Box 1 . 
same comparison after explicitly considering the reinvestment of earnings. Based on this analysis the section advances some conclusions on how the reform could affect the economic value of firms when the tax law is fully implemented. Section 4 presents the results of simulation exercises that seek to resolve the problem of firms choosing between the two taxation regimes and debt versus equity post-reform. Section 5 summarizes.

\section{BOX 1: The 2014-2015 Tax Reform in a Nutshell}

In addition to the changes to the corporate and personal income tax discussed in this paper, aimed at achieving greater neutrality and equality of the tax system, the reform also modifies other taxes including specific taxes on alcoholic and non-alcoholic beverages, tobacco, and financial transactions; the VAT to construction, capital gains tax on real estate and environmental taxes. In addition, the reform also increases the capacity of the Tax Authority to detect and reduce evasion and elusion.

The taxes on alcoholic and non-alcoholic beverages, as well as tobacco, aim at reducing the consumption of products considered harmful for people. In particular, the reform raises the levy on alcoholic beverages and on soft drinks with a high concentration of sugar, while decreasing the one on soft drinks without sugar. Similarly, tax on tobacco products were modified to avoid consumers shifting to lower quality products which were subject to lower taxes -overall, the average price of a pack of cigarettes is expected to increase by about $23 \%$ and the dispersion of prices decrease.

The stamp-tax rate on credit transactions was doubled (exemptions were maintained), while the cap on the value of new constructions exempt of the VAT was reduced. Also, capital gains on real estate -which until the reform were either tax-exempt or subject to a unique tax, for individuals who are not in the business of buying-selling real estate- became subject to a cap of UF 8,000 (about USD 300,000). The cap applies cumulatively over the lifetime of each individual and any excess over the cap becomes taxable under the personal income tax. Environmental excise taxes were established for the import of diesel vehicles and the use of industrial heaters and turbines.

Finally, the reform changes some of the existing incentives for small firms. In particular, it raises from 4 to $6 \%$ the deduction allowed for the purchase of fixed-assets, reduces the annual sales cap under which small firms in agriculture, mining and transport are allowed to pay taxes on an alleged or presumed amount rather than on actual earnings, and increased six-fold the annual sales cap under which firms can use a simplified accounting system for tax purposes. 


\section{ALTERNATIVE TAX SYSTEMS}

One key and almost unique feature of the Chilean income tax system -until the 2014 reform- has been that in it there is no double taxation, that is, earnings are taxed only once ${ }^{3}$. This occurs because corporate and personal taxes are fully integrated, i.e., the corporate tax becomes a credit for shareholders when paying their individual income taxes on the dividends received. In other words, the corporate tax is paid by the firm "on behalf" of its shareholders -the firm withholds the tax- and becomes a credit when individuals file their own personal income taxes, where their income includes the dividends received. Thus, in the end individuals pay only the difference between the corporate tax rate and their marginal personal income tax rate (or get a reimbursement if theirs is lower than the corporate tax rate). As will be discussed below, this property is partially lost under the new cash-based system (alternative 2).

\subsection{The pre-reform tax system}

The pre-reform tax system is fully integrated and only distributed earnings are taxable at the individual level, leaving retained earnings temporarily exempt from personal income taxes until they are distributed to the shareholders (the personal income tax on retained earnings is waived or deferred until those are distributed). To better understand how this works image a firm whose assets generate $\$ 1$, which is subject to a corporate income tax of $20 \%$ and whose owner is subject to a marginal personal income tax of $35 \%$. Assume also that the firm distributes half of the earnings as dividends and retains the other half (see Annex Table 1). After corporate taxes the firm is left with $\$ 0.8$ and distributes $\$ 0.4$ as dividend. This amount carries a tax credit of $\$ 0.1$ (half of the corporate tax paid by the firm), which means that the shareholder's income base amounts to $\$ 0.5$ (its wealth increases in $\$ 0.4$ received as dividend and $\$ 0.1$ as a tax credit). Given her personal income tax rate the payable tax amounts to $\$ 0.175$ (\$ $0.5 \times 0.35)$. Since she has a credit of $\$ 0.1$, the out-of-pocket money is only $\$ 0.075$ and the overall tax rate paid over the distributed earnings is $0.35(0.175 / 0.5)$, which is the shareholder's marginal rate (if her personal tax rate had been lower than $20 \%$ the tax authority would have reimbursed the difference to her). The earnings retained by the firm will have the same treatment in the future when distributed (see Annex Table 1, column 2).

Table 1 in the Annex also analyzes the same situation under the assumption that the investor finances the firm's asset with debt (a bond). In this case the firm does not pay corporate taxes on the asset returns because these correspond to interest paid to the investor. This amount (\$1) is entirely part of the investor's taxable income, while the retention for reinvestment purposes is a new loan granted by the investor to the firm to be repaid free of taxes in the future (see row 4, columns 3 and 4 in Table 1). All taxes are paid by the investor in the first period, $t_{0}$.

3 It should be noted that double taxation on sales was eliminated in Chile with the introduction of the VAT in 1974. Since then many countries have introduced VATs, making it a much more common feature in countries' tax systems. 
It should be noted that the total amount received (and taxes paid) by the investor is the same (see rows 10 and 11); the only difference between debt and equity financing is the timing of when taxes are paid and cash flows received. Also, in the example the bond holder still receives a positive cash flow the first period equal to $\$ 0.15$, but had the firm distributed less than $\$ 0.35$ (retained more than $\$ 0.65$ ) he would have suffered a negative cash-flow in $t_{0}$.

\subsection{The new accrual-based system (alternative 1)}

This alternative keeps the personal and corporate income taxes fully integrated, but because is based on accrued profits, it eliminates the waiver or deferral on retained earnings - shareholders are liable for all the earnings generated by the firm in $t_{0}$, irrespective of whether those are distributed or retained. In addition, under this alternative the corporate income tax rate increases to $25 \%$. Thus, under this alternative and irrespective of the amount distributed, in $t_{0}$ the firm pays $\$ 0.25$ for each dollar generated and the shareholder whatever additional amount is needed to comply with her taxes ( $\$ 0.1$ if her personal tax rate is 0.35 as in the example). Annex Table 2 shows the cash flows in $t_{0}$ and $t_{1}$ for the shareholder using the same parameters as in Table 1 (except for the corporate tax rate).

Note that if the firm does not distribute enough dividends the shareholder could face a liquidity problem as she would have to pay taxes for earnings she has not yet received - in the example the firm needs to distribute at least $\$ 0.1$ to avoid this situation (Table 2, column 1). This occurs because the shareholder pays taxes on all accrued earnings (\$ 1) and not only the fraction distributed (\$ 0.5). It is likely that to avoid this liquidity problem to their shareholders, firms will be forced to increase the dividends payout ratio, thus reducing their retention ratio and possibly overall investment ${ }^{4}$. To ameliorate the adverse effect on firms' investment, especially those believed to have limited access to external finance, for small firms ${ }^{5}$ the law provides a tax incentive consisting of a temporary deduction from the firm's taxable income (i.e., firms are allowed to declare as an expense) an amount equal to $50 \%$ of the earnings retained 6 . This deduction occurs in the year when the investment takes place and generates a savings in taxes equal to $25 \%$ (the corporate tax rate) of the deduction (see Annex Table 2, columns 1 and 3, row 4). The deduction, however, becomes taxable income for the individual shareholder when retained earnings are distributed in the future (Table 2, row 8, column 4).

Finally, since shareholders pay taxes on an accrual basis, retained earnings are fully "take-home money" when distributed in $t_{1}$, as taxes were all paid in $t_{0}$ when earnings were generated (except for the deduction just discussed in the case of small firms; Table 2, columns 2 and 4, row 6).

4 The effect on investment holds to the extent that firms are credit constrained.

5 Small firms are those with total annual sales of about USD 3.9 million or less.

6 The deduction has a cap of about USD 158,000 which is reached when reinvestment amounts to about USD 316,000 . 
Table 2 in the Annex also reproduces the cash flows under the assumption that the asset is financed with debt through a company-issued bond instead of shares. The figures, shown in columns 5 and 6, are identical to those in Annex Table 1, columns 3 and 4. Again, in the three alternatives all taxes paid and cash flows received are identical (see rows 12 and 13), with the difference being when the taxes are paid and cash flows received, a difference that will play a role when calculating present values. It is worth noting that for large firms equity financing produces a larger cash flow in $t_{0}$ (and lower in $t_{1}$ ) than debt, although the investor's taxable income and accrued tax is the same, because in the former case the amount retained and reinvested is lower due to the payment of corporate taxes. The fact that under debt-financing the firm has more resources available for investment $(\$ 1)$ than under equity-financing $(\$ 0.75)$ plays an important role when the firm has profitable investment opportunities (see Section 4 below). The amount available for potential investments in the case of small firms $(0.8125)$ falls in between the other cases.

\subsection{The new cash-based system (alternative 2)}

Under this alternative the corporate tax rate increases to $27 \%$, the shareholder pays taxes only on distributed earnings (retained earnings are not taxable until distributed), but the system is semi-integrated as only $65 \%$ of the corporate tax can be used as a credit for shareholders -thus, there is partial double taxation since $35 \%$ of distributed earnings do not receive the corresponding corporate tax credit, hence, pay taxes twice. With these changes the maximum rate paid on firms' earnings increases from $35 \%$ under alternative 1 to $44.45 \%$ under alternative 2 (see last row in Annex Table 3, large firms). Retained earnings, when distributed to shareholders in the future, also receive as a credit only $65 \%$ of the proportional corporate tax paid in $t_{0}$. Note that under this alternative the shareholder will not face a liquidity problem as she always pays taxes only on distributed earnings.

Because of similar reasons as those in 2.2 above, the new tax code provides the same incentive for the reinvestment of earnings in the case of small firms, i.e., a deduction as an expense of an amount equal to $50 \%$ of the total investment ${ }^{7}$. Annex Table 3 shows the cash flows received by the shareholders in $t_{0}$ and $t_{1}$ using the same parameters - personal income tax (0.35) and dividends payout ratio (0.5)- as in Annex Tables 1 and 2. Note that because the deduction (half of the retained earnings) is not subject to corporate taxes in $t_{0}$, it does not carry a credit in $t_{1}$-in other words, only half of the retained earnings (the fraction taxed in $t_{0}$ ) receive credit for the corporate taxes paid in $t_{0}$ (Annex Table 3, column 4, row 7). This implies a lowering of the double taxation as half of the retained earnings pay taxes only once (when distributed). In the example this means a final tax rate of 42.01 instead of $44.45 \%$ (row 14, Annex Table 3).

The last columns in Table 3 show the cash flows if the assets are financed with debt; the results are the same as those in Tables 1 and 2. As debt is not subject to double taxation, it produces the lower overall tax burden -although the cash flow in

7 The credit cap is the same as in footnote 6. 
$t_{0}$ is also the lowest. And again, the total amount available for potential investment (\$1) is the largest under debt financing and the lowest under equity-financing for large firms ( $\$ 0.73)$; the case of small firms under equity- financing falls in between because of the lower taxes paid in $t_{0}$ due to the tax incentive.

\section{THE CASH FLOW FOR THE SHAREHOLDER AND THE ECONOMIC VALUE OF FIRMS}

Following the same rationale used in the construction of Annex Tables 1 through 3, it is possible to compute the cash flow received by investors under the three alternative tax regimes and when the asset is either debt- or equity financed, as a function of the unknown parameters which are specific to the firm and individual investor, namely, the dividend payout ratio, $\alpha$, and the investor's (marginal) personal income tax rate 8 , $\lambda_{P}$. This is done in Tables 5 and 6 in the Annex. Annex Table 4 summarizes these results by skipping the intermediate steps. In what follows we focus on the results in Annex Table 4.

From the comparison of columns 1 through 4 in Table 4 some conclusions emerge which shed light on the gains or losses associated with the tax reform.

a. First, unless the payout ratio equals 1 , pre-reform the cash flow in $t_{0}$ is larger -and the cash flow in $t_{1}$ lower- under equity than under debt-financing (columns 1 and 4). For this reason -i.e., that cash flows in PV terms are worth more- equity-financing should be the preferred option, except because the total amount reinvested is larger under debt (last two rows). If the firm has profitable investment opportunities then debt may become the preferable option.

b. The same applies when comparing the post-reform equity financing under the accrual system and debt for the case of large firms; the accrual system delivers a larger cash flow in $t_{0}$ (and lower in $t_{1}$ ), except when $\alpha$ equals 1 , but permits a smaller reinvestment amount (columns 2 and 4, rows B, D and J).

c. The total cash flow for shareholders (equity-financing) of large firms (row F) is always smaller under alternative 2 (cash-based system) than under alternative 1 (accrual-based), the pre-reform system, and debt-financing - the total cash flow under the last three is identical. This occurs because of the partial double taxation under the new cash-based system. The difference in the cash flow, 0.0945, is exactly the tax credit lost $(0.27 \times 0.35)$ and affects all taxpayers irrespective of their personal income tax rate, $\lambda_{P}$.

d. The amount reinvested by large firms (row $\mathbf{J}$ ) is highest under debt financing and lowest under equity-financing under the cash-based system. The reinvestment

8 The (marginal) personal income tax on interest or dividends is the total amount of taxes accrued on the dividends or interest received, as a share of the latter. Note that total taxes paid may be an average of several tax rates if the dividends or interest received trigger a jump in the shareholder's tax bracket. In what follows we refer to the taxes paid on dividends or interest as the marginal personal income tax. 
amount under equity and the accrual system is in between, but lower than in the pre-reform regime?

e. Under equity-financing, if the dividends payout ratio equals 1 (there are no retained earnings), small and large firms are identical and both should prefer the accrual based system (alternative 1) - column 3, rows E and F. This occurs because if there is no reinvestment of earnings, small firms cannot benefit from the associated tax incentives and earnings become fully subject to double taxation.

f. The total cash flow received by a shareholder of a small firm under the cash-based system (row E) increases with the retention ratio $(1-\alpha)$, reaching a maximum when the payout ratio $(\alpha)$ equals zero. This happens because under alternative 2 the reinvestment of earnings reduces double taxation. However, even when $\alpha$ equals zero the total cash flow is lower under alternative 2 than under the pre-reform system, the accrual-based system (alternative 1) or debt financing.

g. Finally, the future cash flow (in $t_{1}$ ) is greater in the cash-based system (alternative 2 ) than the accrual based system (alternative 1), for large firms, when the personal income tax rate on dividends $\left(\lambda_{P}\right)$ is less than $15.55 \%$ (Table 4 , columns 2 and 3 , row D) ${ }^{10}$.

But the choice between tax systems post-reform under equity-financing, or debtfinancing, does not depend only on the total cash flow received (total taxes paid), but also on when flows are received (the PV of the cash flows), and the return obtained on reinvested earnings. Hernández (2015) presents a more detailed comparison of cash flows between the pre- and post-reform tax systems, for small and large firms, and concludes that there are few general results as the choice is firm and investor specific -depends on $\alpha$ and $\lambda_{p}$ as well as the rate of return on investment. One result is that under equity financing firms will generally prefer the accrual-based system because of the lower tax burden- in other words, firms will avoid the cash-based system because of the double taxation.

There is another conclusion worth repeating here because it is relevant for understanding the empirical results presented in Section 4 below. The new accrual based system implies moving the payment of taxes forward as all taxes get paid in $t_{0}$. This implies that for investors with a marginal personal income tax rate $\left(\lambda_{p}\right)$ below 0.25 (the corporate rate), the reimbursement of taxes occurs earlier, in $t_{0}$, and therefore they will prefer the accrual-based to the pre-reform system or even debt-financing. This is true for large and small firms ${ }^{11}$ (Annex Table 4, columns 1, 2 and 4).

Although the effect of the reform on the economic valuation of a firm is investor and firm specific, as it depends on the firm's dividends payout ratio and the investor's

9 This results from the different corporate taxes paid.

${ }^{10}$ This occurs because under the accrual based system the cash flow in $t_{1}$ is constant and equal to the amount retained by the firm, since all taxes are paid in $t_{0}$. In the cash based system, however, the cash flow in $t_{1}$ depends on the personal income tax rate, $\lambda_{P}$, net of the effects of a higher corporate tax rate $\left(\lambda_{C}=27 \%\right)$ and the smaller credit equal to $65 \%$ of the corporate tax paid.

${ }^{11}$ For small firms the condition for this result to hold is even less stringent; what is needed is that $\lambda_{P}<0.25$ $(1+\alpha)$. This results from imposing the condition $\mathrm{CF}_{1}{ }^{\mathrm{PR}}>\mathrm{CF}_{1}{ }^{\mathrm{AC}}$, where $\mathrm{CF}_{1}{ }^{\mathrm{PR}}$ and $\mathrm{CF}_{1}{ }^{\mathrm{AC}}$ are the cashflows in $t_{1}$ under the pre-reform and post-reform accrual regime, respectively. 
personal (marginal) income tax rate, it can be argued that, in general, large and small firms will be worth less after the reform because of the following reasons:

a. If they choose alternative 2 , the total tax burden increases by $9.45 \%$ in the case of large firms and by $0.0945 \cdot \vartheta$ in the case of small firms, where $1 \leq \vartheta \leq 0.5$, hence reducing shareholders' total cash flow;

b. If they choose alternative 1 , and prior to the reform it was worthwhile for shareholders to postpone the payment of taxes by reinvesting earnings, as the reform eliminates this possibility the firm will be worth less;

c. If alternative 1 is not a possibility because the firm is not owned exclusively by individuals, the cash-based system becomes mandatory and the firm is subject to a higher debt burden;

d. For some shareholders, in particular those who cannot use the tax credit derived from the corporate income tax -institutional investors such as pension funds and insurance companies-, the increase in the corporate tax rate from 20 to $27 \%$ means a loss of net worth;

e. Even if firms choose debt-financing after the reform to ameliorate its impact, and presumably debt was an option prior to the reform, it can be argued that the choice is a second-best aimed at minimizing the loss of economic value - otherwise the firm was not optimizing its value before the reform.

Nevertheless, the loss in value can be partly compensated if shares are bought by those who gain with the reform -i.e., if a 'clientele effect' follows the reform-namely, individuals with personal income tax rates below $25 \%$, who would be willing to pay more for the shares ${ }^{12}$. This option, however, is limited only to firms for which, given their ownership structure, the accrual system is a possibility.

This result should not come up as a surprise. Indeed, as the corporate tax rate rises from 20 to either 25 or $27 \%$, taxes on dividends are either paid earlier or a fraction of them become subject to double taxation, it is expected that the value of firms will decrease because of the higher tax burden on capital profits. After all the tax reform is expected to increase government revenues by about $3 \%$ of GDP once fully implemented, and a big part of this is expected to come from taxes on capital.

\section{CHOOSING BETWEEN DEBT, EQUITY AND TAX REGIMES}

Sections 2 and 3 shed some light on the possible effects of the tax reform on the firms' economic valuation, their choice between debt- and equity-financing, and within the latter between the two new tax regimes. However, except for a few cases, in the majority of them the conclusion is unclear as it depends on the firm's payout ratio and the investor's personal income tax rate applicable to dividends or interest. To provide more insight on the issue, in this section we present some results after simulating different

12 These individuals would buy shares from those subject to higher tax rates who, in turn, in the past preferred higher reinvestment ratios (and probably were able to impose such decision on others). 
scenarios with alternative values for the key parameters of the model. Before proceeding, however, subsection 4.1 provides some insights into the model used.

\subsection{Maximizing the PV of Cash Flows}

We model the problem faced by the representative investor as choosing the financingmix and the tax regime that maximizes the present value of cash flows received from the firm. Further, the model assumes only two periods: $t_{0}$, when earnings are generated, and $t_{1}$, when retained earnings are distributed along with the associated return ${ }^{13}$.

It follows that the analysis is valid only to the extent that the following assumption holds: "investors only care about the discounted value of cash flows received from the firm"; that is, that they seek to maximize the present value of the dividends or interest stream net of taxes. This is certainly a strong assumption as investors may in fact be motivated by other reasons; for instance, they may seek power or influence through wealth accumulation -they may derive welfare from being 'powerful' because of their wealth. In such a case investors may decide to retain earnings and see their firms grow even if doing so increases their tax burden.

Without denying that there might be other reasons why firms or investors opt among alternative tax systems and financing options than just maximizing the PV of a cash flow, we follow the standard approach used by the profession in analyzing this kind of problems. Further, it should be noted that our conclusions below still hold if these other reasons do not change with the tax reform. In other words, our conclusions remain valid if everything remains constant and investors care about the PV of cash flows in addition of other reasons. In the example above investors may still decide to retain earnings, but choose the accrual-based over the cash-based tax regime; if the latter is not an option, they may decide not to retain earnings but use the proceeds to provide a loan to their firm instead.

With regards to the two-period choice, it should be noted that this is used only for presentational purposes, but the assumption can be easily lifted. The reason we choose a two-period model is because the representative investor faces the same problem with earnings generated by the firm every period. Since the problem repeats identically every period, once a solution has been found for the cash flow in $t_{0}$, the same solution applies in subsequent periods (unless the value of exogenous variables change).

It should also be noted that in our setting the time elapsing since earnings are retained until they are distributed is undetermined -in other words, the period $t_{1}-t_{0}$ may represent any number of years. In fact $t_{1}$ in the model is the time when the firm decides how and when retained earnings will be distributed and the corresponding taxes paid ${ }^{14}$. It can correspond to the time when the investment undertaken with retained earnings matures and is sold to a third party or kept by the firm (for additional discussion see Hernández, 2015). The effect of a longer period $t_{1}-t_{0}$ is captured in the model by assuming a higher discount rate.

13 For a similar setting see De Gregorio, 2014.

14 The cash flows that occur in $t_{1}$ according to the model may not represent actual cash flows, but the PV of future cash flows that start in $t_{1}$. 


\subsection{Reasons to retain earnings}

Before proceeding with the simulation results we briefly discuss one extension to the model, namely, we explicitly consider the possibility of retained earnings being a channel to elude or avoid taxes.

The analysis in Sections 2 and 3 above assumes a time-invariant personal income tax rate on dividends $\left(\lambda_{P}{ }^{0}=\lambda_{P}{ }^{1}=\lambda_{P}\right.$, where the superscript refers to the time period when taxes are paid). However, the investor can incur in tax planning to reduce her future personal income tax rate applicable to dividends $\left(\lambda_{P}{ }^{1}\right)$, a mechanism that we vaguely define as tax avoidance or tax elusion ${ }^{15}$.

Analytically we can write the total cash flow received by the shareholder, in PV terms, as follows:

$$
\begin{gathered}
\text { PV } \left.(\text { Cash-Flow })=\text { [earnings distributed in } t_{0}\right] \\
+ \text { PV [retained earnings }(1+r)]
\end{gathered}
$$

where $r$ is the net return obtained on the undertaken investment.

Letting $t_{1}$ be the period when the investment project matures, (1) can be rewritten as:

$$
\begin{gathered}
\text { PV }(\text { Cash-Flow })=\left[\text { earnings distributed in } t_{0}\right] \\
+ \text { PV }\left[\text { earnings retained in } t_{0} \text { but distributed in } t_{1}\right] \\
+ \text { PV }\left[\text { return on retained earnings, also distributed in } t_{1}\right]
\end{gathered}
$$

Since our interest is on the payout ratio, $\alpha$, in what follows we assume for simplicity that the return on retained earnings, $r$, is given and constant.

Note that under the pre-reform tax system the total cash flow, for small and large firms, does not depend on the payout ratio when $\lambda_{P}$ is constant (see column 1 , rows $\mathrm{E}$ and $\mathrm{F}$ in Table 4). Thus, except for the return made on the investment of retained earnings, there is no gain for the shareholders in reducing the payout ratio (doing so postpones receiving net of taxes dividends). However, if shareholders can take steps such that retained earnings, when distributed, pay a lower tax rate $\lambda_{P}{ }^{1}<\lambda_{P}{ }^{0}$, then their total cash flow can increase with the retention rate $(1-\alpha)$. This can be seen by rewriting the total cash flow as follows (for simplicity we omit in (2) below present value calculations and the net return on investment):

$$
\begin{gathered}
\text { Total cash flow }=\alpha\left(1-\lambda_{P}^{0}\right)+(1-\alpha)\left(1-\lambda_{P}{ }^{1}\right)=\alpha\left(1-\lambda_{P}{ }^{0}\right)+(1-\alpha) \\
\left(1-\lambda_{P}{ }^{0}+\Delta \lambda_{P}\right)=\left(1-\lambda_{P}{ }^{0}\right)+(1-\alpha) \Delta \lambda_{P}, \text { where } \Delta \lambda_{P}=\lambda_{P}{ }^{0}-\lambda_{P}{ }^{1}
\end{gathered}
$$

Equation (2) shows how the incentive to retain earnings arises when $\Delta \lambda_{P}>0$, i.e., when shareholders can reduce their marginal personal income tax rate on received dividends by undertaking tax planning activities leading to tax avoidance (the incentive persists as long as $\Delta \lambda_{P}$ is large enough to compensate for the loss in present value terms that results from the postponement of dividends).

In the pre-reform tax system and due to the existence of loopholes in the tax code, investors were in fact able to reduce their personal marginal income tax rates on

15 Tax avoidance or elusion is understood as the result, in the form of a lower tax burden, of undertaking tax planning activities. This can be expressed as $\lambda_{P}^{1}=(1-\varphi) \lambda_{P}^{0}$, where $\varphi$ represents the elusion coefficient. 
retained earnings. This was possible, for instance, by transforming retained earnings into higher stock prices and then capital gains, which are non-taxable for individuals who buy and sell stocks sporadically. But also by moving undistributed profits among firms (withdrawing them from one firm to capitalize another) until retained earnings were parked in a firm where, de jure or de facto, the applicable tax rate was lower. One possibility was by buying a company with a large stock of accumulated past losses, while other was to invest in companies subject to specific tax rules, like small agricultural firms that pay taxes not on actual earnings but on alleged or presumed profits ${ }^{16}$. This loophole and others identified by the Chilean tax authorities were significantly closed with the 2014 reform; now retained earnings become fully taxable immediately after being withdrawn from the firm which originated them, irrespective of whether they are used for consumption or investment in other firms.

Although retained earnings may continue to be used as a mechanism to reduce tax obligations (the final result will depend on the capacity of shareholders and tax experts to find new loopholes under the new tax code), on a priori basis it is expected that such incentive will decrease after the reform. This is so because under alternative 1 (fully integrated accrual based system) all taxes are paid in $t_{0}$, while under alternative 2 (semi integrated cash based system), which allows postponing taxes until earnings are distributed, the corporate tax rate is higher ( 27 instead of 25 percent) and the tax credit amounts to only $65 \%$ of the corporate tax, which makes undertaking tax avoidance activities more expensive.

There is another reason to retain earnings, namely, the possibility to undertake profitable investments, which may play an important role for credit constrained firms. Tables 5 and 6 in the Annex show the total cash flow for large and small firms, respectively, under all three tax systems and debt- versus equity-financing.

In the case of large firms (Annex Table 5) it is easy to see that not only the total cash-flow for the investor is the lowest among all alternatives in the case of the equitysemi-integrated tax system, but choosing alternative 2 over alternative 1 reduces the total cash flow available for reinvestment in $t_{0}$ by 0.02 (compare columns 2 and 3 , row 5). If a large firm is keen to reinvest, choosing alternative 2 over alternative 1 not only increases the overall tax burden, but leaves less resources available for such purpose.

Small firms do obtain additional resources for investment post reform for $(1-\alpha)$ $>0.4$ due to the new tax incentive ${ }^{17}$ (Annex Table 6). However, irrespective of (1- $\alpha$ ) alternative 2 frees less resources for investment than alternative 1 . And both alternatives provide less resources than debt-financing. In other words, even for credit constrained small firms which are eager to invest the cash-based tax system results less attractive.

\subsection{Minimizing the present value of total taxes paid}

We start by asking the following question: which financing and tax regime choice minimizes the total amount of taxes paid in PV terms? This is answered by calculating the PV of total taxes paid by the investor and the firm under each alternative, for

\footnotetext{
16 Presumed profits are calculated as a fixed percentage of the value of land. Consequently, firms are not required to have accounting for tax purposes.

17 Note that this effect operates as long as the tax incentive does not reach the ceiling mentioned in footnote 6 .
} 
specific values of the parameters in the model: the pay-out ratio, $\alpha$, the marginal personal income tax rate, $\lambda_{p}$, the discount rate, $\delta$, and the tax elusion coefficient, $\varphi$. Starting points are the equations shown in Annex Table 7, which show the total taxes paid in $t_{0}$ and $t_{1}$ under each regime. Table 1 below shows the values assumed for each parameter in our simulations.

\section{TABLE 1}

\section{ALTERNATIVE VALUES OF KEY PARAMETERS USED IN SIMULATIONS OF TOTAL TAXES PAID}

\begin{tabular}{|l|c|c|}
\hline \multicolumn{1}{|c|}{ Parameter } & Number of alternatives & Values range between \\
\hline pay-out ratio, $\alpha$ & 21 & $0.00-1.00$ (increments of 0.05 ) \\
personal income tax rate, $\lambda_{\mathrm{p}}$ & 8 & $0.00-0.35$ (increments of 0.05 ) \\
discount rate, $\delta$ & 11 & $0.00-0.50$ (increments of 0.05 ) \\
tax elusion coefficient, $\varphi$ & 5 & $0.00-0.80$ (increments of 0.20 ) \\
\hline
\end{tabular}

The discount rate, needed to calculate present values, can be either interpreted as the investors' intertemporal rate of substitution (a higher discount rate means more impatient investors), or the rate of return of potential investment projects foregone by the firm (a higher rate means more profitable investment projects). In both cases a higher rate can also be interpreted as a longer period elapsing between $t_{0}$ and $t_{1}$. Finally, the tax avoidance coefficient, $0<\varphi<1$, is used to calculate a net of elusion tax rate in $t_{1}, \lambda_{P}{ }^{1}$, where the latter is equal to $\lambda_{P}{ }^{0} \cdot(1-\varphi)$. We assume that tax avoidance applies to all taxable incomes whose corresponding taxes can be legally deferred, that is, retained earnings under the semi-integrated or cash based system for all firms, and for small firms in either tax regime, to $1 / 2$ of the earnings reinvested that are tax exempt in $t_{0}$ (but taxable in $t_{1}$ ) given the new incentive provided for investment post-reform.

Annex Tables 8.A through 8.F present the percentage of firms preferring different possibilities of equity-financing versus debt for both the pre-reform and post reform regimes. Each table presents results for all possible values of the elusion coefficient and discount rate. Thus, every entry in the tables represent the percentage out of 168 possible cases ( 21 values for $\alpha$ and 8 values for $\lambda_{p}$ ). For the pre-reform there is only one table (8.A) because there is only one tax regime and no difference by firm size, while for the post-reform in the case of large firms the accrual system is identical to debt-financing, so only one table is needed (8.B).

The conclusions are straightforward. Pre-reform (Table 8.A) the majority of investors are indifferent or prefer equity, especially when elusion -via retained earnings- increases. Even though equity permits delaying the payment of taxes, a fraction of investors still prefer debt. These are the ones whose personal tax rate is below the corporate rate ( 20 percent) and, therefore, receive a tax refund. For these investors waiting for their refund is not the preferred option. This also explains why the share of investors preferring equity decreases when the discount rate increases. 
For large firms (Table 8.B) the preferred option post-reform is either the equityaccrual-based system or debt, which are identical, with the semi-integrated system being preferred only when elusion is possible and relatively high (elusion occurs only by the deferral of taxes under the semi integrated system). The discount rate plays the same role described above.

For small firms (Annex Tables 8.C-8.E) the preferred option is equity under the accrual system, followed by either debt or the semi-integrated system, which becomes the preferred option only when elusion is possible and relatively high. However, Tables 8.C-8.E include the cases when there is indifference between regimes. To draw a more precise conclusion Table 8.F looks at the percentage of small firms preferring one regime versus another but excluding cases of indifference. Although the accrual system continues being the preferred option, the semi integrated system dominates over debt.

\subsection{Maximizing the present value of cash flows}

The results discussed above, albeit intuitive and easy to interpret, present an incomplete answer to the question of which financing option and tax regime maximizes the value of the firm for investors. The reasons are that minimizing taxes is not exactly the same than maximizing the PV of cash flows ${ }^{18}$, and that the equations in Annex Table 7 do not consider the return on the investment undertaken with retained earnings, an element that can be important for credit constrained firms.

Next, we present the results of simulations based on the cash flow equations presented in Annex Table 4, in PV terms. Before proceeding note that we need to add a new parameter, namely, the rate of return on investments undertaken by the firm, $r$ (see rows I and $\mathrm{J}$ in Annex Table 4). In addition, to reduce the number of iterations we use only two possible values for the discount rate, $\delta$, 'low' and 'high' (the reason for this becomes apparent when discussing the results below). Alternative values for the key parameters in the model are the same as those in Table 1 above, except for $r$ and $\delta$ which are presented in Table 2 .

\section{TABLE 2}

ALTERNATIVE VALUES OF KEY PARAMETERS USED IN SIMULATIONS OF CASH-FLOWS

\begin{tabular}{|l|c|l|}
\hline \multicolumn{1}{|c|}{ Parameter } & Number of alternatives & \multicolumn{1}{|c|}{ Values range between } \\
\hline Discount rate $(\delta)$ & 2 & $10 \%$ and $30 \%$ \\
Annual return on investment $(r)$ & 11 & $0.00-0.50$ (increments of 0.05) \\
\hline
\end{tabular}

18 If the purpose is to minimize the payment of taxes firms might set $\alpha$ equal to zero and never distribute past earnings, a solution that does not necessarily maximizes the investor's cash flow. 
Simulations again assume that tax elusion is possible for all tax deferrals that are permitted by law, but does not apply to taxes paid on the return obtained on investments financed with retained earnings. Results are presented in Annex Tables 9.A through 9.P for small and large firms, pre- and post-reform. The results do not include cases of indifference and have the same interpretation as before: each entry is the percentage of firms out of 168 possible cases that prefer one alternative over another.

For the situation pre-reform (Tables 9.A-9.D) the following conclusions can be drawn: the majority of firms would choose equity over debt when the return on investment, $r$, is lower than the discount rate, $\delta$, but debt becomes the preferred option when the opposite is true. This is so because debt-financing frees more resources for investment as no corporate tax is paid in $t_{0}$ (see Annex Table 5, row 5). Even when $r \leq \delta$ some investors still prefer debt, however, which can be explained because of their personal tax rate $\left(\lambda_{P}\right)$ being lower than the corporate rate $\left(\lambda_{\mathrm{c}}\right)$, which makes them eligible for a tax refund. The preference for equity increases with elusion, as expected.

More important, for large firms the election post reform (Tables 9.E-9.J) is mainly between equity-accrual system and debt, with very few cases choosing the equitysemi-integrated system ${ }^{19}$. The latter is chosen only when elusion is relatively high, but always by a small fraction of firms. The role of $r$ versus $\delta$ is the same discussed earlier: there is a significant shift from equity-accrual to debt when $r>\delta$ and vice versa. The case of small firms post reform (Tables 9.K-9.P) follows exactly the same pattern, with the only differences being that the fraction of firms choosing equitysemi-integrated is even smaller, and that the shift of firms from equity-accrual to debt when $r>\delta$ (or vice versa) is somehow less striking ${ }^{20}$.

The results in Tables 9 refer to the case when firms can choose among three alternatives, namely, equity-accrual, equity-semi-integrated and debt financing. However, the amendment to the Tax Law introduced in early 2016 precluded the former option for firms whose owners are not all individuals. Tables Annex 10.A through 10.H present the result of choosing between equity and debt financing, when the accrual system is not an option. The conclusions are consistent with the ones above: firms predominantly choose debt financing; the preference for debt increases when $r>\delta$ (or decreases when $r<\delta$ ); and equity financing increases with elusion (although debt predominates as the preferred option even for the highest elusion coefficient).

\section{SUMMARY AND CONCLUSIONS}

This paper analyzes how firms' financing decisions (debt versus equity) and firms' economic value may change as a result of the 2014-2015 tax reform in Chile. The approach consists of looking at the final cash flows received by investors, in present value terms, and comparing those with the situation pre-reform. We compare

19 For additional insights into why the accrual system is preferred to the semi-integrated system see Hernandez (2015).

20 This can be explained because, depending on the value of (1- $\alpha)$, post reform the amount of resources available for investment in the case of small firms can be significantly larger than that for large firms (Row 5, Annex Table 6). 
the situation pre-reform with the situation post-reform after the reform has been fully implemented -we don't look at intermediate solutions that may occur during the transition years when corporate tax rates are being raised. It should be stressed that the conclusions of the paper are valid under the assumption that investors care only about the discounted value of the cash flows received, that is, that they maximize the present value of the dividends or interest stream, net of taxes, under a positive intertemporal rate of substitution. Further, the conclusions of the paper are still valid even if there exist other reasons why firms opt among alternative tax systems and financing options, to the extent that these other reasons do not change with the tax reform.

The main conclusions of the paper are the following:

- Retained earnings are expected to be lower vis-à-vis the pre-reform tax regime, because the reform attempts to close many of the loopholes present in the tax code which enabled firms to undertake tax avoidance.

- The economic value of firms is expected to be lower after the reform, if firms opt for the cash-based or semi-integrated tax system, because of double taxation. This will be the case of firms that due to their ownership structure cannot opt-out of the semi-integrated system.

- Debt financing is expected to be higher than before the reform, especially for firms for which the accrual system is not an option, because of double taxation under equity financing.

- For individuals whose personal income tax rate on dividends is higher than $25 \%$, the choice between both post-reform tax systems depends on the firm's payout ratio. However, the economic value of firms will be lower vis-à-vis the pre-reform system either because of double taxation or because taxes are paid earlier.

- The economic value of firms will increase -vis-à-vis the pre-reform system- for shareholders of firms that opt for the accrual-based system and whose personal income tax rates are below $25 \%$, which occurs because tax refunds happen early.

- As the reform raises the corporate tax rate, it reduces the value of firms for institutional investors that do not benefit from the associated tax credit under either the fully- or semi- integrated system.

- Given a set of plausible values for the key parameters determining the PV of cash flows received by investors, we find that most firms (if allowed) will choose the fully integrated or accrual based-system after the reform. Firms start shifting to the semi-integrated system only after tax avoidance or elusion is allowed and significantly large. Even though such shift occurs, the majority of firms will choose debt to equity when the fully integrated system is not an option.

Based on the findings above it could be argued, albeit tentatively, that as a mediumterm consequence of the reform firms will either invest less, become more vulnerable because of their higher reliance on debt, or a combination of both.

The first effect is a direct result of the lower return on equity (lower value of firms) due to the higher tax burden in PV terms, or because of the smaller volume available to invest after corporate taxes in the case of credit constrained firms. The second effect results from firms increasing their leverage precisely to avoid the higher tax burden, which makes them more prone to encounter liquidity problems when facing a 
slowdown. The greater financial fragility occurs because of the lesser risk sharing under debt -whereas dividends can be higher during booms but reduced during slowdowns, interest payments are fixed and not dependent on the state of the economy. This result can be ameliorated if other prudential measures are taken, such as (self) imposing caps on firms' leverage, which in turn reduces investment. Another alternative is to include risk-sharing clauses in debt contracts where interest payments are made contingent on the state of the economy. This feature, albeit conceptually appealing, increases transactions costs by creating moral hazard problems -the experience with such clauses in the case of sovereign debt issuance has not been a very successful one (Bank of England, 2015 ; Barr, Bush and Pienkowski, 2014; Blanchard, Mauro and Acalin, 2016; Borensztein and Mauro, 2004).

There are a few caveats to the effects discussed above which are worth mentioning. First, the second effect does not mean that debt should be avoided, but should result from some optimization process by the firm where risk-sharing and other dimensions are considered. The point here is that the tax reform may be artificially inducing a behavior that makes firms depart from such optimum. Second, neither can be inferred from the first effect that overall investment and hence growth will be affected adversely. This, because of the use the government makes of the additional taxes collected -in fact if, as intended, the resources are spent in human capital (education) overall growth can be even higher in the long-term. More generally, the two effects discussed above reflect a partial equilibrium analysis, whereas a proper assessment of the effects of the reform on investment and overall macro-financial fragility of the Chilean corporate sector requires building a general equilibrium model. Such exercise is well beyond the scope of this paper and should be addressed separately.

\section{REFERENCES}

BANK OF ENGLAND (2015). "Summary of Bank of England workshop on GDP-linked bonds", (http:// www.bankofengland.co.uk/research/Documents/conferences/gdplinkedbonds.pdf)

BARR, D., O. BUSH and A. PIENKOWSKI (2014). "GDP-linked bonds and sovereign default", Bank of England Working Paper.

BLANCHARD, O., P. MAURO and J. ACALIN (2016). "The case for growth indexed bonds in advanced economies", Peterson Institute Policy Brief, PB16-2.

BORENSZTEIN, E. and P. MAURO (2004). "The case for GDP indexed bonds", Economic Policy 19 (38).

DE GREGORIO, J. (2014). "Notas sobre la reforma tributaria", Peterson Institute of International Economics, June. http://www.econ.uchile.cl/uploads/publicacion/323a9f13862a7fc0679b09e9c564378d8eafc363.pdf

HERNANDEZ, L. (2015). "Chile's 2014 tax reform: Choosing Between the Accrued- and Cash-based tax systems". Unpublished manuscript, October.

KATSZ, R. (2014). "Reforma Tributaria, Impuestos 'Verdes' e Implicancias de Política Ambiental”. Puntos de Referencia, CEP, April.

LIBRARY OF CONGRESS, CHILE (2014). "Reforma Tributaria 2014", in http://www.bcn.cl/leyfacil/ recurso/reforma-tributaria-2014.

MINISTRY OF FINANCE, CHILE (2014a). "Mapa de la Reforma Tributaria”, in http://reformatributaria. gob.cl/

MINISTRY OF FINANCE, CHILE (2014b). "Proyecto de Ley de Reforma Tributaria: Indicaciones al proyecto de ley para implementar el Protocolo de Acuerdo". Presentation to the Chilean Senate, Finance Committee, August.

VIDAURRE, B. (2014). “Reforma Tributaria 1ª Parte: ¿Cómo Quedará la Tributación de las Empresas $y$ de las PYME?’. Serie Informe Legislativo 38, L\&D, November. 


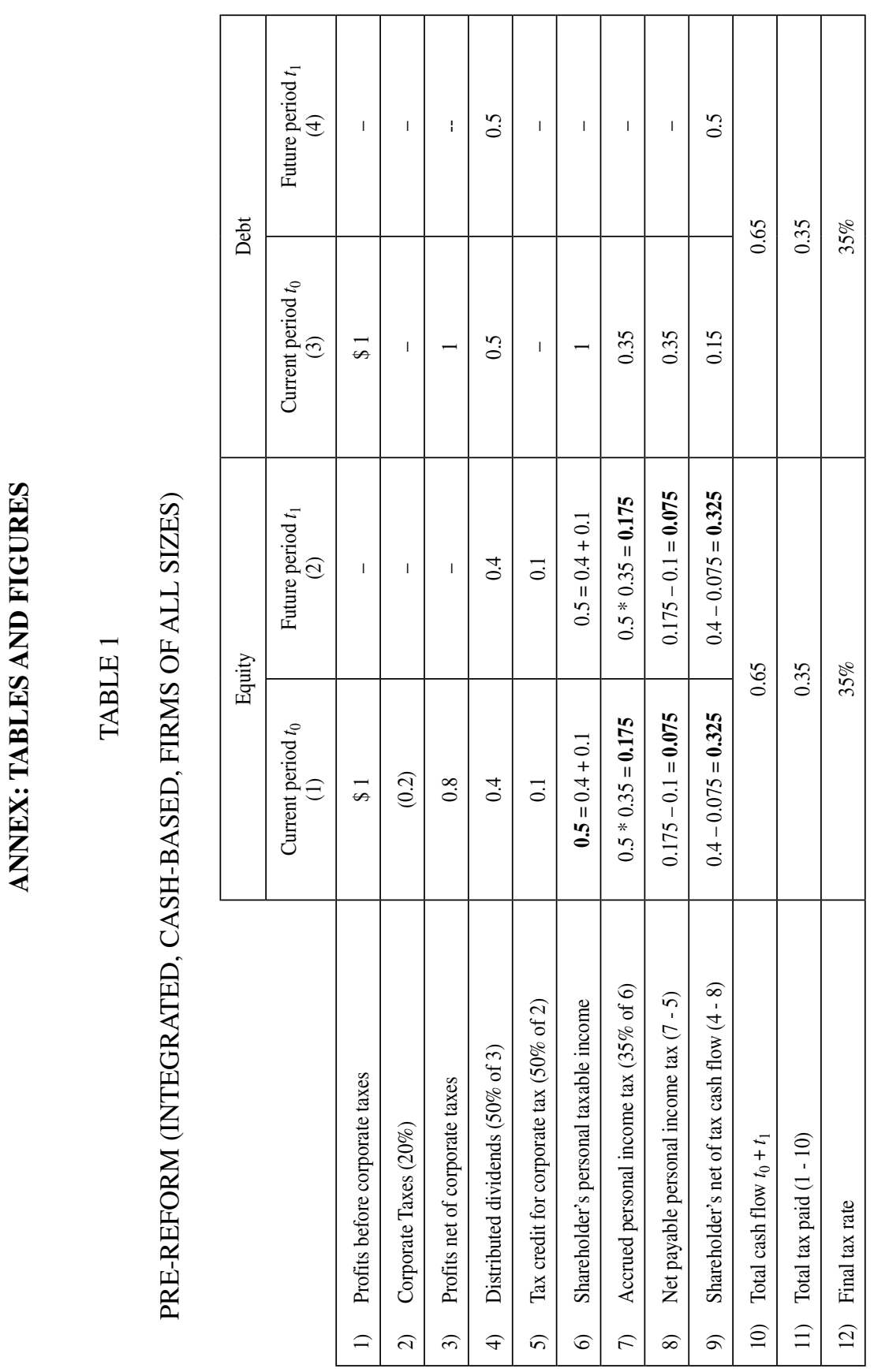




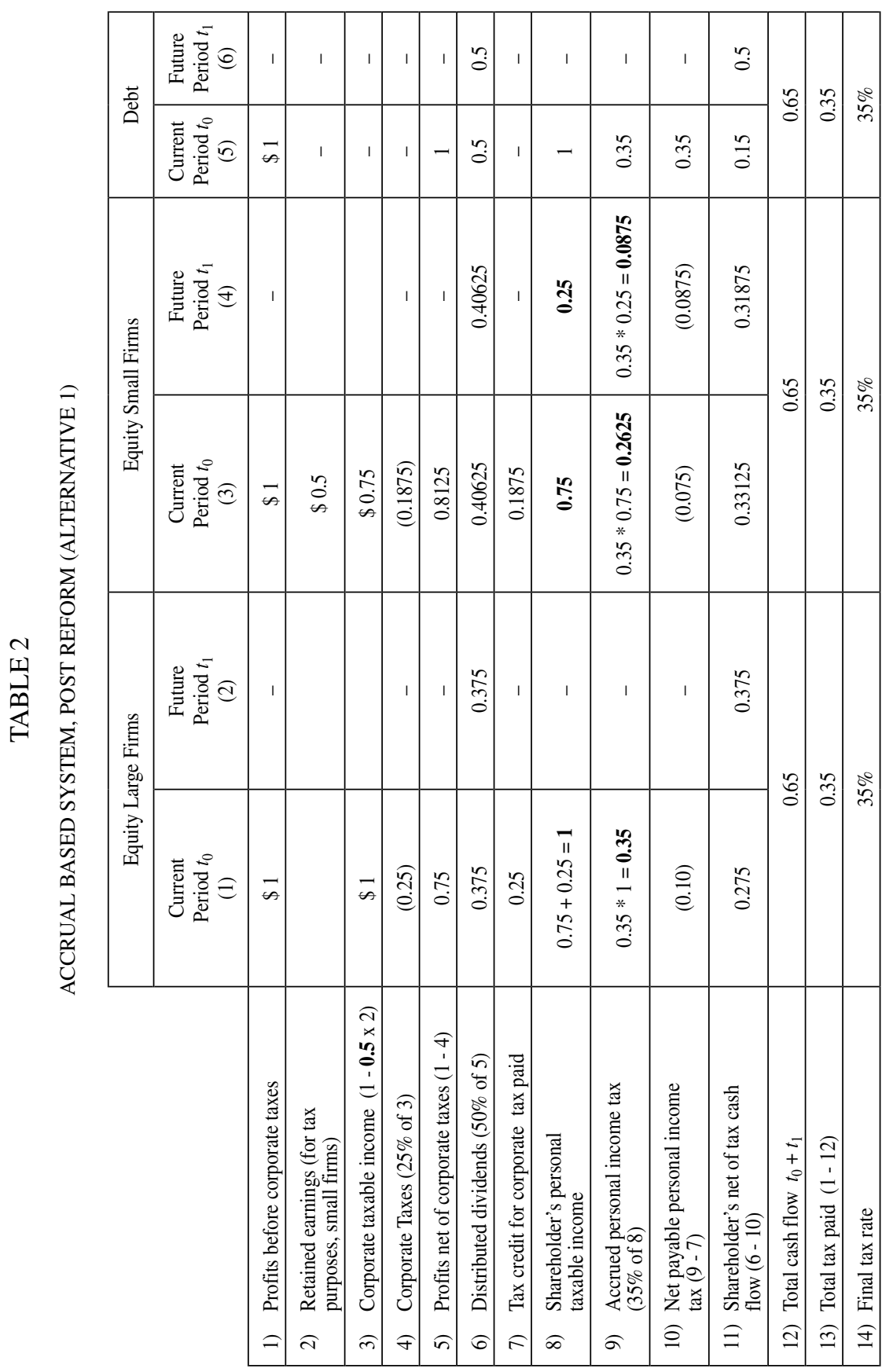




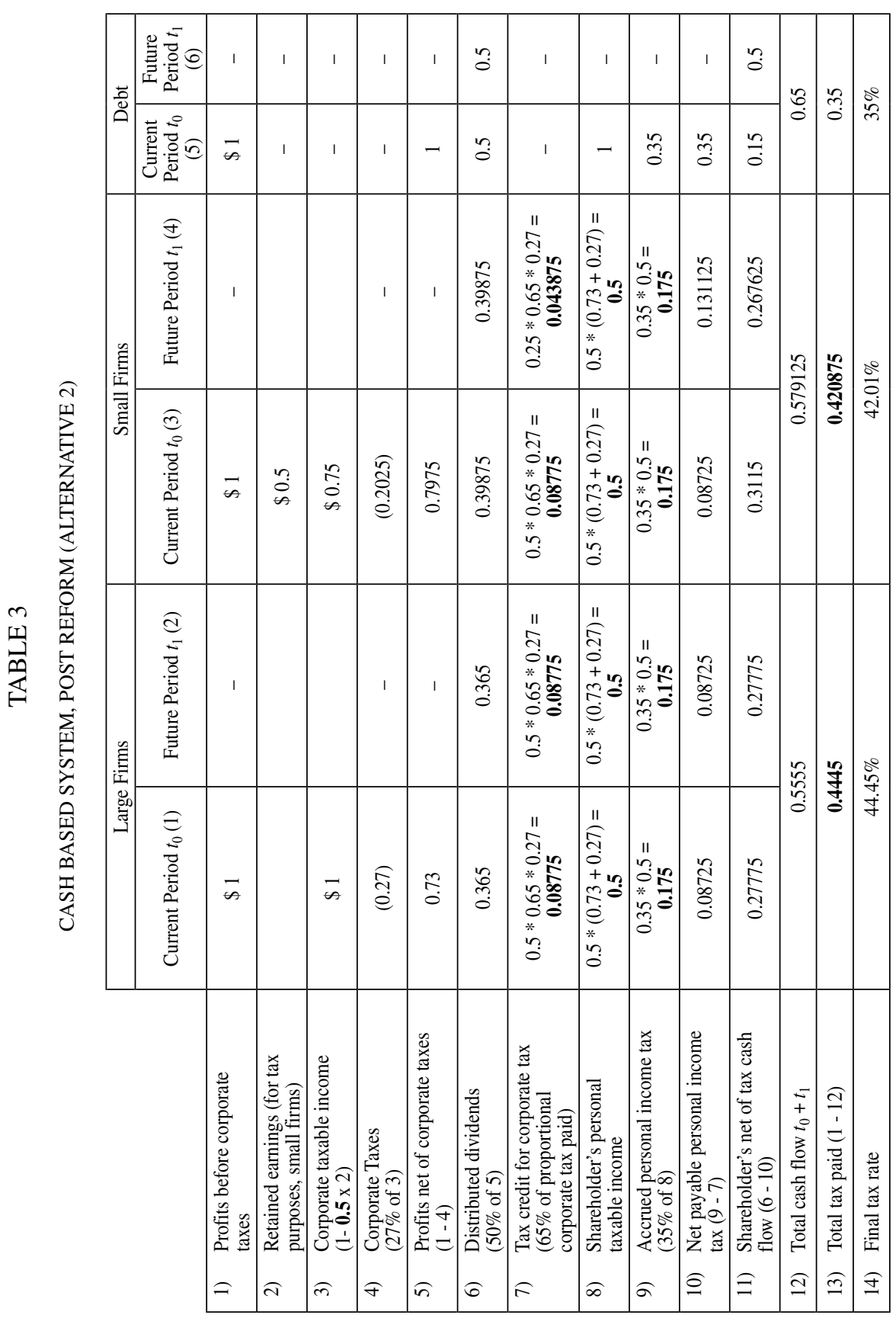




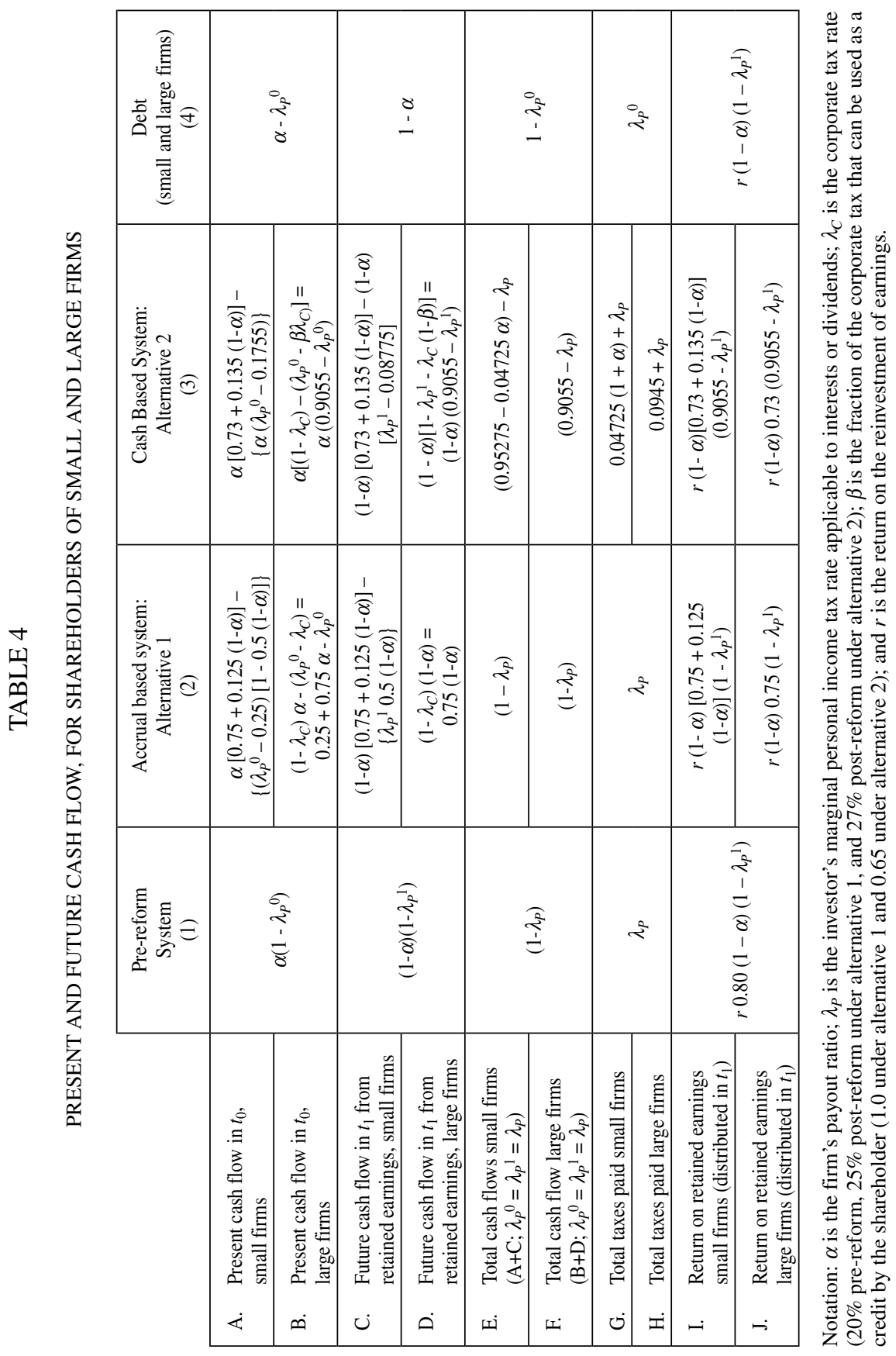




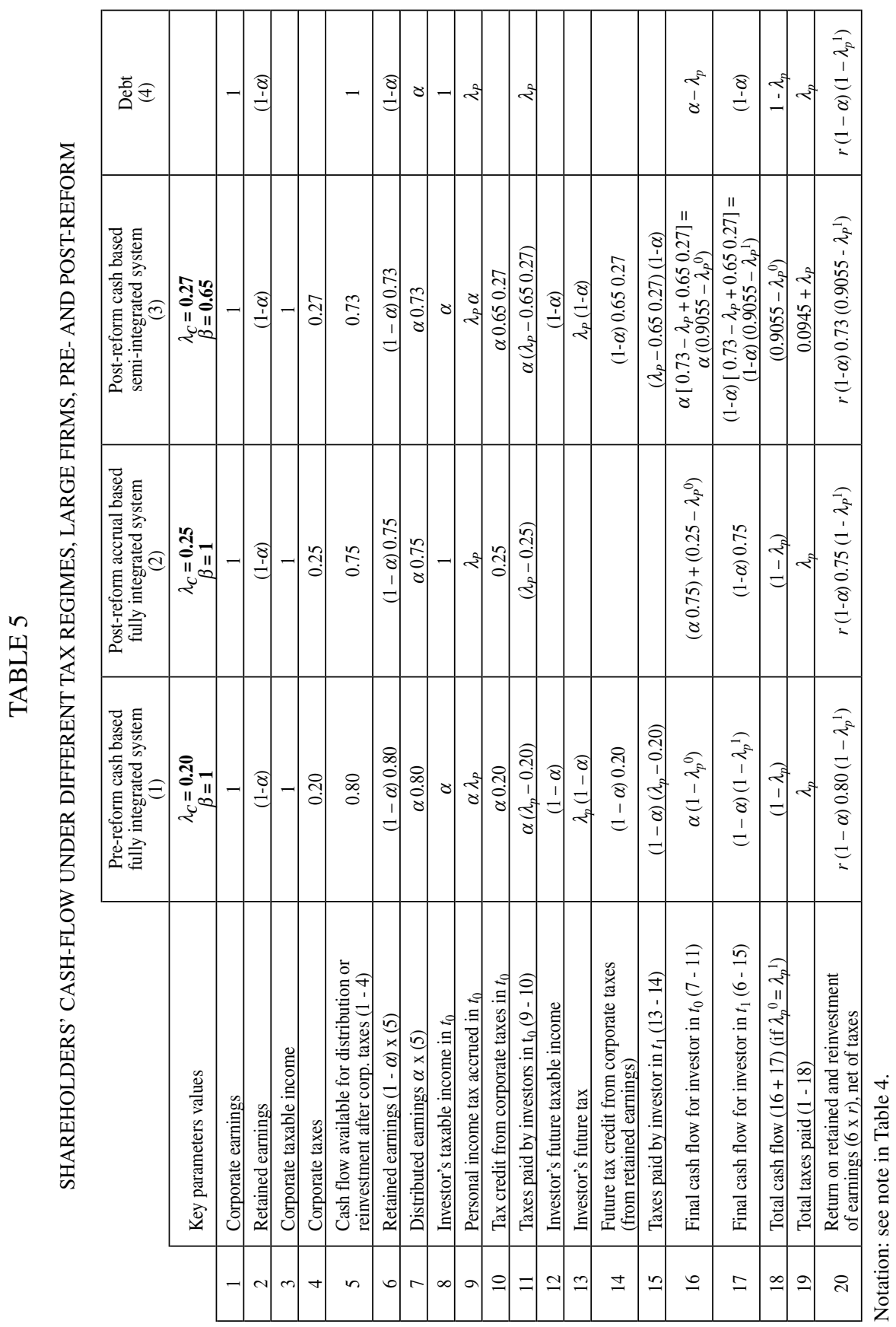




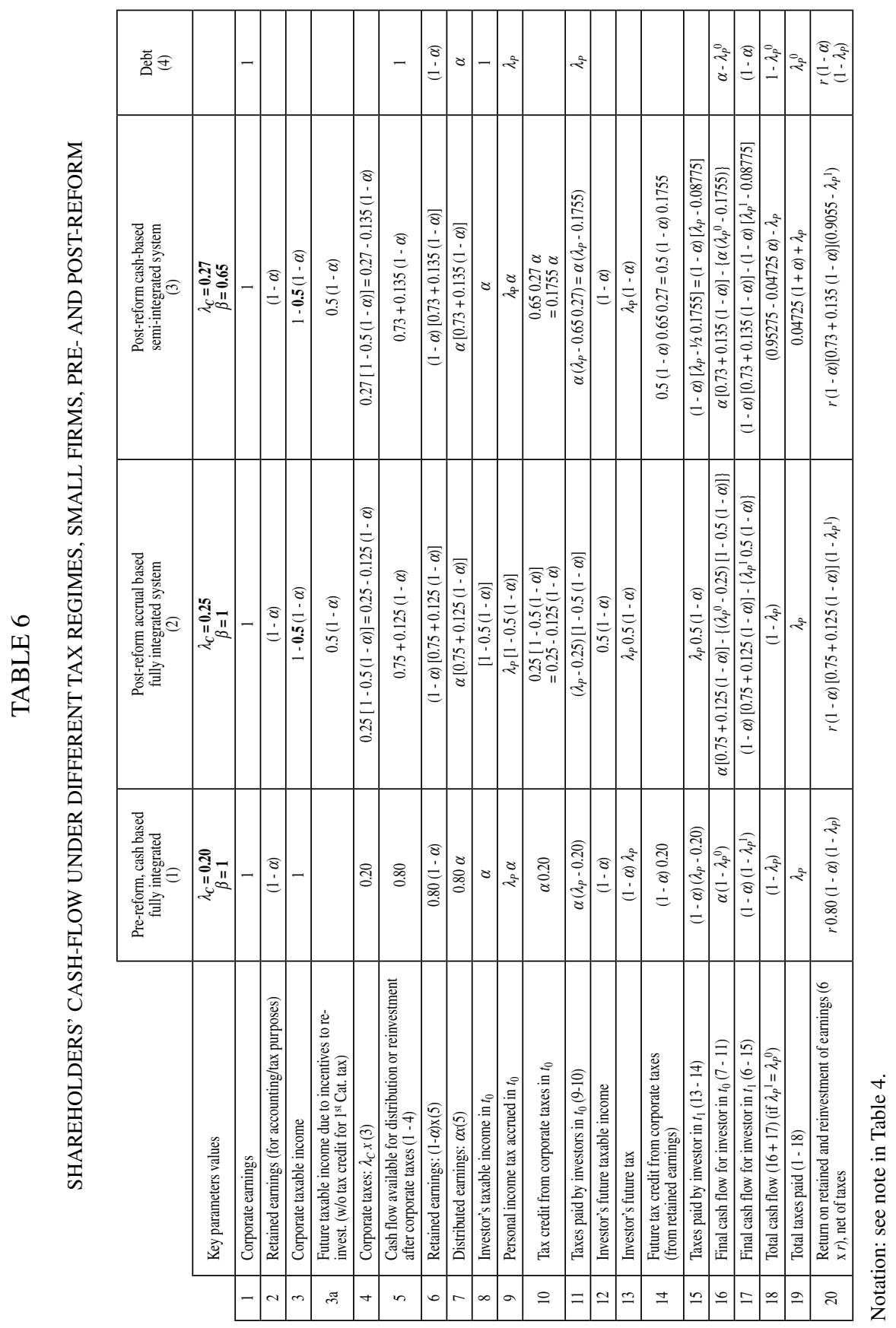




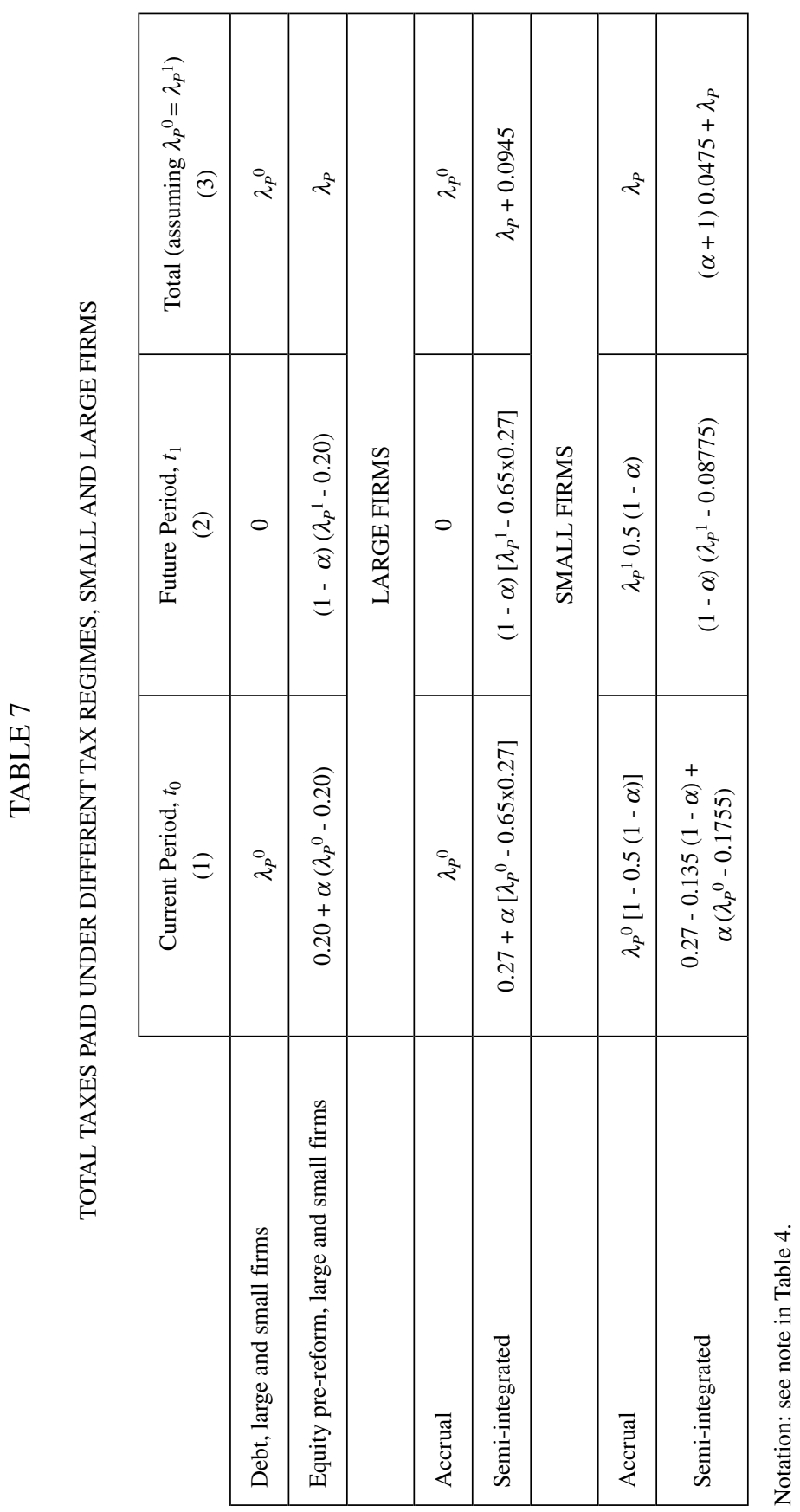




\section{TABLE 8}

RESULTS FROM SIMULATION EXERCISES, MINIMUM TAXES (IN PV TERMS)

\section{Pre-Reform, all firms}

\begin{tabular}{|c|c|c|c|c|c|c|c|c|c|c|c|}
\hline \multicolumn{12}{|c|}{$\begin{array}{l}\text { 8.A. Percentage of firms for which equity is equal or preferable to debt (PV of taxes is same or } \\
\text { lower) }\end{array}$} \\
\hline \multirow{2}{*}{ elusion } & \multicolumn{11}{|c|}{ discount rate } \\
\hline & 0.00 & 0.05 & 0.10 & 0.15 & 0.20 & 0.25 & 0.30 & 0.35 & 0.40 & 0.45 & 0.50 \\
\hline 0.00 & 1.00 & 0.52 & 0.52 & 0.52 & 0.52 & 0.52 & 0.52 & 0.52 & 0.52 & 0.52 & 0.52 \\
\hline & 1.0 & 0.8 & 0.7 & 0.7 & 0.7 & 0. & 0. & 0. & 0. & 0.6 & 0.64 \\
\hline 0.40 & 1.00 & 0.88 & 0.88 & 0.76 & 0.76 & 0.7 & 0.76 & 0.76 & 0.76 & 0.64 & 0.64 \\
\hline 0.60 & 1.00 & 0.88 & 0.88 & 0.88 & 0.88 & 0.76 & 0.76 & 0.76 & 0.76 & 0.76 & 0.76 \\
\hline 0.80 & 1.00 & 0.88 & 0.88 & 0.88 & 0.88 & 0.88 & 0.76 & 0.76 & 0.76 & 0.76 & 0.76 \\
\hline
\end{tabular}

Post-Reform, large firms

8.B. Percentage of firms for which equity (+ semi integrated) is equal or preferable to debt (PV taxes is same or lower)

\begin{tabular}{|c|c|c|c|c|c|c|c|c|c|c|c|}
\hline \multirow{3}{*}{ elusion } & \multicolumn{10}{|c|}{ discount rate } \\
\cline { 2 - 12 } & 0.00 & 0.05 & 0.10 & 0.15 & 0.20 & 0.25 & 0.30 & 0.35 & 0.40 & 0.45 & 0.50 \\
\hline 0.00 & 0.00 & 0.00 & 0.00 & 0.00 & 0.00 & 0.00 & 0.00 & 0.00 & 0.00 & 0.00 & 0.00 \\
0.20 & 0.00 & 0.00 & 0.00 & 0.00 & 0.00 & 0.00 & 0.00 & 0.01 & 0.01 & 0.01 & 0.01 \\
0.40 & 0.08 & 0.08 & 0.08 & 0.08 & 0.08 & 0.08 & 0.08 & 0.08 & 0.08 & 0.08 & 0.08 \\
0.60 & 0.21 & 0.20 & 0.19 & 0.18 & 0.17 & 0.17 & 0.16 & 0.16 & 0.15 & 0.15 & 0.15 \\
0.80 & 0.31 & 0.29 & 0.28 & 0.26 & 0.26 & 0.24 & 0.24 & 0.23 & 0.23 & 0.22 & 0.22 \\
\hline
\end{tabular}

Post-Reform, small firms

8.C. Percentage of firms for which the accrual system is preferable or equal to the semi-integrated system

\begin{tabular}{|c|c|c|c|c|c|c|c|c|c|c|c|}
\hline \multirow{2}{*}{ elusion } & \multicolumn{10}{|c|}{ discount rate } \\
\cline { 2 - 12 } & 0.00 & 0.05 & 0.10 & 0.15 & 0.20 & 0.25 & 0.30 & 0.35 & 0.40 & 0.45 & 0.50 \\
\hline 0.00 & 1.00 & 1.00 & 1.00 & 1.00 & 1.00 & 1.00 & 1.00 & 1.00 & 1.00 & 1.00 & 1.00 \\
0.20 & 1.00 & 1.00 & 1.00 & 1.00 & 1.00 & 1.00 & 1.00 & 0.99 & 0.99 & 0.99 & 0.99 \\
0.40 & 0.95 & 0.95 & 0.95 & 0.95 & 0.95 & 0.95 & 0.95 & 0.95 & 0.95 & 0.95 & 0.95 \\
0.60 & 0.86 & 0.87 & 0.88 & 0.88 & 0.89 & 0.89 & 0.89 & 0.89 & 0.89 & 0.90 & 0.90 \\
0.80 & 0.79 & 0.80 & 0.80 & 0.81 & 0.82 & 0.83 & 0.83 & 0.84 & 0.84 & 0.85 & 0.85 \\
\hline
\end{tabular}


8.D. Percentage of firms for which Equity + Accrual system is preferable or equal to debt

\begin{tabular}{|c|c|c|c|c|c|c|c|c|c|c|c|}
\hline \multirow{2}{*}{ elusion } & \multicolumn{10}{|c|}{ discount rate } \\
\cline { 2 - 11 } & 0.00 & 0.05 & 0.10 & 0.15 & 0.20 & 0.25 & 0.30 & 0.35 & 0.40 & 0.45 & 0.50 \\
\hline 0.00 & 1.00 & 1.00 & 1.00 & 1.00 & 1.00 & 1.00 & 1.00 & 1.00 & 1.00 & 1.00 & 1.00 \\
0.20 & 1.00 & 1.00 & 1.00 & 1.00 & 1.00 & 1.00 & 1.00 & 1.00 & 1.00 & 1.00 & 1.00 \\
0.40 & 1.00 & 1.00 & 1.00 & 1.00 & 1.00 & 1.00 & 1.00 & 1.00 & 1.00 & 1.00 & 1.00 \\
0.60 & 1.00 & 1.00 & 1.00 & 1.00 & 1.00 & 1.00 & 1.00 & 1.00 & 1.00 & 1.00 & 1.00 \\
0.80 & 1.00 & 1.00 & 1.00 & 1.00 & 1.00 & 1.00 & 1.00 & 1.00 & 1.00 & 1.00 & 1.00 \\
\hline
\end{tabular}

8.E. Percentage of firms for which Equity + Semi-integrated is preferable or equal to debt

\begin{tabular}{|c|c|c|c|c|c|c|c|c|c|c|c|}
\hline \multirow{2}{*}{ elusion } & \multicolumn{10}{|c|}{ discount rate } \\
\cline { 2 - 11 } & 0.00 & 0.05 & 0.10 & 0.15 & 0.20 & 0.25 & 0.30 & 0.35 & 0.40 & 0.45 & 0.50 \\
\hline 0.00 & 0.01 & 0.01 & 0.01 & 0.01 & 0.01 & 0.02 & 0.03 & 0.04 & 0.05 & 0.07 & 0.08 \\
0.20 & 0.05 & 0.08 & 0.09 & 0.11 & 0.12 & 0.14 & 0.14 & 0.16 & 0.17 & 0.17 & 0.18 \\
0.40 & 0.22 & 0.23 & 0.23 & 0.23 & 0.24 & 0.24 & 0.24 & 0.26 & 0.26 & 0.26 & 0.26 \\
0.60 & 0.33 & 0.33 & 0.32 & 0.32 & 0.32 & 0.32 & 0.32 & 0.32 & 0.32 & 0.32 & 0.32 \\
0.80 & 0.41 & 0.40 & 0.40 & 0.40 & 0.40 & 0.39 & 0.39 & 0.39 & 0.39 & 0.38 & 0.38 \\
\hline
\end{tabular}




\section{F. Percentage of firms preferring equity (semi-integrated and accrual) vs debt, excluding cases of indifference}

\begin{tabular}{|c|c|c|c|c|c|c|c|c|c|c|c|c|}
\hline \multirow{3}{*}{ elusion } & \multicolumn{12}{|c|}{ discount rate } \\
\hline & \multicolumn{3}{|c|}{0.00} & \multicolumn{3}{|c|}{0.05} & \multicolumn{3}{|c|}{0.10} & \multicolumn{3}{|c|}{0.15} \\
\hline & Accrual & Semi & Debt & Accrual & Semi & Debt & Accrual & Semi & Debt & Accrual & Semi & Debt \\
\hline 0.00 & - & - & - & 0.83 & 0.00 & 0.00 & 0.83 & 0.00 & 0.00 & 0.83 & 0.00 & 0.00 \\
\hline 0.20 & 0.83 & 0.00 & 0.00 & 0.83 & 0.00 & 0.00 & 0.83 & 0.00 & 0.00 & 0.83 & 0.00 & 0.00 \\
\hline 0.40 & 0.79 & 0.05 & 0.00 & 0.79 & 0.05 & 0.00 & 0.78 & 0.05 & 0.00 & 0.78 & 0.05 & 0.00 \\
\hline 0.60 & 0.70 & 0.14 & 0.00 & 0.70 & 0.13 & 0.00 & 0.71 & 0.13 & 0.00 & 0.71 & 0.12 & 0.00 \\
\hline 0.80 & 0.62 & 0.21 & 0.00 & 0.64 & 0.20 & 0.00 & 0.64 & 0.20 & 0.00 & 0.64 & 0.19 & 0.00 \\
\hline \multirow{3}{*}{ elusion } & \multicolumn{12}{|c|}{ discount rate } \\
\hline & \multicolumn{3}{|c|}{0.20} & \multicolumn{3}{|c|}{0.25} & \multicolumn{3}{|c|}{0.30} & \multicolumn{3}{|c|}{0.35} \\
\hline & Accrual & Semi & Debt & Accrual & Semi & Debt & Accrual & Semi & Debt & Accrual & Semi & Debt \\
\hline 0.00 & 0.83 & 0.00 & 0.00 & 0.83 & 0.00 & 0.00 & 0.83 & 0.00 & 0.00 & 0.83 & 0.00 & 0.00 \\
\hline 0.20 & 0.83 & 0.00 & 0.00 & 0.83 & 0.00 & 0.00 & 0.83 & 0.00 & 0.00 & 0.83 & 0.01 & 0.00 \\
\hline 0.40 & 0.78 & 0.05 & 0.00 & 0.78 & 0.05 & 0.00 & 0.79 & 0.05 & 0.00 & 0.79 & 0.05 & 0.00 \\
\hline 0.60 & 0.72 & 0.11 & 0.00 & 0.72 & 0.11 & 0.00 & 0.72 & 0.11 & 0.00 & 0.72 & 0.11 & 0.00 \\
\hline 0.80 & 0.65 & 0.18 & 0.00 & 0.67 & 0.17 & 0.00 & 0.67 & 0.17 & 0.00 & 0.67 & 0.16 & 0.00 \\
\hline \multirow{3}{*}{ elusion } & \multicolumn{12}{|c|}{ discount rate } \\
\hline & \multicolumn{3}{|c|}{0.40} & \multicolumn{3}{|c|}{0.45} & \multicolumn{3}{|c|}{0.50} & & & \\
\hline & Accrual & Semi & Debt & Accrual & Semi & Debt & Accrual & Semi & Debt & & & \\
\hline 0.00 & 0.83 & 0.00 & 0.00 & 0.83 & 0.00 & 0.00 & 0.83 & 0.00 & 0.00 & & & \\
\hline 0.20 & 0.83 & 0.01 & 0.00 & 0.83 & 0.01 & 0.00 & 0.81 & 0.01 & 0.00 & & & \\
\hline 0.40 & 0.79 & 0.05 & 0.00 & 0.79 & 0.05 & 0.00 & 0.79 & 0.05 & 0.00 & & & \\
\hline 0.60 & 0.73 & 0.11 & 0.00 & 0.73 & 0.10 & 0.00 & 0.73 & 0.10 & 0.00 & & & \\
\hline 0.80 & 0.67 & 0.16 & 0.00 & 0.68 & 0.15 & 0.00 & 0.68 & 0.15 & 0.00 & & & \\
\hline
\end{tabular}

Note: values in the first three cells are not reported because firms are indifferent between all alternatives. 


\section{TABLE 9}

RESULTS FROM SIMULATION EXERCISES, MAXIMUM CASH FLOWS (IN PV TERMS), EXCLUDING CASES OF INDIFFERENCE

Pre-Reform, all firms

\begin{tabular}{|c|c|c|c|c|c|c|c|c|c|c|c|}
\hline \multicolumn{12}{|c|}{$\begin{array}{l}\text { 9.A. Percentage of firms preferring equity, discount } \\
\text { rate }=10 \%\end{array}$} \\
\hline \multirow{2}{*}{ elusion } & \multicolumn{11}{|c|}{ return on investment } \\
\hline & 0.00 & 0.05 & 0.10 & 0.15 & 0.20 & 0.25 & 0.30 & 0.35 & 0.40 & 0.45 & 0.50 \\
\hline 0.0 & 0.83 & 0.71 & 0.48 & 0.36 & 0.24 & 0.12 & 0.00 & 0.00 & 0.00 & 0.00 & 0.00 \\
\hline 0.2 & 0.83 & 0.83 & 0.71 & 0.71 & 0.60 & 0.60 & 0.48 & 0.48 & 0.36 & 0.36 & 0.24 \\
\hline 0.4 & 0.83 & 0.83 & 0.83 & 0.71 & 0.71 & 0.71 & 0.60 & 0.60 & 0.60 & 0.48 & 0.48 \\
\hline 0.6 & 0.83 & 0.83 & 0.83 & 0.83 & 0.71 & 0.71 & 0.71 & 0.71 & 0.60 & 0.60 & 0.60 \\
\hline 0.8 & 0.83 & 0.83 & 0.83 & 0.83 & 0.83 & 0.71 & 0.71 & 0.71 & 0.71 & 0.71 & 0.60 \\
\hline \multicolumn{12}{|c|}{$\begin{array}{l}\text { 9.B. Percentage of firms preferring debt, discount } \\
\text { rate }=10 \%\end{array}$} \\
\hline \multirow{2}{*}{ elusion } & \multicolumn{11}{|c|}{ return on investment } \\
\hline & $\mathbf{0 . 0 0}$ & 0.05 & 0.10 & 0.15 & 0.20 & 0.25 & 0.30 & 0.35 & 0.40 & 0.45 & 0.50 \\
\hline 0.0 & 0.00 & 0.24 & 0.48 & 0.60 & 0.71 & 0.83 & 0.95 & 0.95 & 0.95 & 0.95 & 0.95 \\
\hline 0.2 & 0.00 & 0.12 & 0.24 & 0.24 & 0.36 & 0.36 & 0.48 & 0.48 & 0.60 & 0.60 & 0.60 \\
\hline 0.4 & 0.00 & 0.12 & 0.12 & 0.24 & 0.24 & 0.24 & 0.36 & 0.36 & 0.36 & 0.48 & 0.48 \\
\hline 0.6 & 0.00 & 0.12 & 0.12 & 0.12 & 0.24 & 0.24 & 0.24 & 0.24 & 0.36 & 0.36 & 0.36 \\
\hline 0.8 & 0.00 & 0.12 & 0.12 & 0.12 & 0.12 & 0.24 & 0.24 & 0.24 & 0.24 & 0.24 & 0.24 \\
\hline
\end{tabular}




\begin{tabular}{|c|c|c|c|c|c|c|c|c|c|c|c|}
\hline \multicolumn{12}{|c|}{$\begin{array}{l}\text { 9.C. Percentage of firms preferring equity, discount } \\
\text { rate }=30 \%\end{array}$} \\
\hline \multirow{2}{*}{ elusion } & \multicolumn{11}{|c|}{ return on investment } \\
\hline & 0.00 & 0.05 & 0.10 & 0.15 & 0.20 & 0.25 & 0.30 & 0.35 & 0.40 & 0.45 & 0.50 \\
\hline 0.0 & 0.83 & 0.83 & 0.71 & 0.71 & 0.60 & 0.60 & 0.48 & 0.48 & 0.36 & 0.36 & 0.25 \\
\hline 0.2 & 0.83 & 0.83 & 0.83 & 0.71 & 0.71 & 0.71 & 0.60 & 0.60 & 0.60 & 0.48 & 0.48 \\
\hline 0.4 & 0.83 & 0.83 & 0.83 & 0.83 & 0.71 & 0.71 & 0.71 & 0.71 & 0.60 & 0.60 & 0.60 \\
\hline 0.6 & 0.83 & 0.83 & 0.83 & 0.83 & 0.83 & 0.71 & 0.71 & 0.71 & 0.71 & 0.71 & 0.60 \\
\hline 0.8 & 0.83 & 0.83 & 0.83 & 0.83 & 0.83 & 0.83 & 0.71 & 0.71 & 0.71 & 0.71 & 0.71 \\
\hline \multicolumn{12}{|c|}{$\begin{array}{l}\text { 9.D. Percentage of firms preferring debt, discount } \\
\text { rate }=30 \%\end{array}$} \\
\hline \multirow{2}{*}{ elusion } & \multicolumn{11}{|c|}{ return on investment } \\
\hline & 0.00 & 0.05 & 0.10 & 0.15 & 0.20 & 0.25 & 0.30 & 0.35 & 0.40 & 0.45 & 0.50 \\
\hline 0.0 & 0.00 & 0.12 & 0.24 & 0.24 & 0.36 & 0.36 & 0.48 & 0.48 & 0.60 & 0.60 & 0.60 \\
\hline 0.2 & 0.00 & 0.12 & 0.12 & 0.24 & 0.24 & 0.24 & 0.36 & 0.36 & 0.36 & 0.48 & 0.48 \\
\hline 0.4 & 0.00 & 0.12 & 0.12 & 0.12 & 0.24 & 0.24 & 0.24 & 0.24 & 0.36 & 0.36 & 0.36 \\
\hline 0.6 & 0.00 & 0.12 & 0.12 & 0.12 & 0.12 & 0.24 & 0.24 & 0.24 & 0.24 & 0.24 & 0.24 \\
\hline 0.8 & 0.00 & 0.12 & 0.12 & 0.12 & 0.12 & 0.12 & 0.24 & 0.24 & 0.24 & 0.24 & 0.24 \\
\hline
\end{tabular}


Post-Reform, Large Firms

\begin{tabular}{|c|c|c|c|c|c|c|c|c|c|c|c|}
\hline \multicolumn{12}{|c|}{$\begin{array}{l}\text { 9.E. Percentage of firms preferring Equity + Accrual System, } \\
\text { rate }=10 \%\end{array}$} \\
\hline \multirow{2}{*}{ elusion } & \multicolumn{11}{|c|}{ return on investment } \\
\hline & 0.00 & 0.05 & 0.10 & 0.15 & 0.20 & 0.25 & 0.30 & 0.35 & 0.40 & 0.45 & 0.50 \\
\hline 0.0 & 0.95 & 0.95 & 0.83 & 0.12 & 0.00 & 0.00 & 0.00 & 0.00 & 0.00 & 0.00 & 0.00 \\
\hline 0.2 & 0.95 & 0.95 & 0.83 & 0.12 & 0.00 & 0.00 & 0.00 & 0.00 & 0.00 & 0.00 & 0.00 \\
\hline 0.4 & 0.87 & 0.88 & 0.77 & 0.08 & 0.00 & 0.00 & 0.00 & 0.00 & 0.00 & 0.00 & 0.00 \\
\hline 0.6 & 0.76 & 0.77 & 0.65 & 0.05 & 0.00 & 0.00 & 0.00 & 0.00 & 0.00 & 0.00 & 0.00 \\
\hline 0.8 & 0.67 & 0.68 & 0.57 & 0.04 & 0.00 & 0.00 & 0.00 & 0.00 & 0.00 & 0.00 & 0.00 \\
\hline \multicolumn{12}{|c|}{$\begin{array}{l}\text { 9.F. Percentage of firms preferring Equity }+ \text { Semi-integrated System, discount } \\
\text { rate }=10 \%\end{array}$} \\
\hline \multirow{2}{*}{ elusion } & \multicolumn{11}{|c|}{ return on investment } \\
\hline & 0.00 & 0.05 & 0.10 & 0.15 & 0.20 & 0.25 & 0.30 & 0.35 & 0.40 & 0.45 & 0.50 \\
\hline 0.0 & 0.00 & 0.00 & 0.00 & 0.00 & 0.00 & 0.00 & 0.00 & 0.00 & 0.00 & 0.00 & 0.00 \\
\hline 0.2 & 0.00 & 0.00 & 0.00 & 0.00 & 0.00 & 0.00 & 0.00 & 0.00 & 0.00 & 0.00 & 0.00 \\
\hline 0.4 & 0.08 & 0.08 & 0.07 & 0.05 & 0.04 & 0.02 & 0.01 & 0.00 & 0.00 & 0.00 & 0.00 \\
\hline 0.6 & 0.19 & 0.18 & 0.18 & 0.16 & 0.14 & 0.12 & 0.09 & 0.07 & 0.06 & 0.04 & 0.03 \\
\hline 0.8 & 0.29 & 0.27 & 0.26 & 0.24 & 0.23 & 0.21 & 0.18 & 0.17 & 0.14 & 0.13 & 0.10 \\
\hline \multicolumn{12}{|c|}{$\begin{array}{l}\text { 9.G. Percentage of firms preferring debt, discount } \\
\qquad \text { rate }=10 \%\end{array}$} \\
\hline \multirow{2}{*}{ elusion } & \multicolumn{11}{|c|}{ return on investment } \\
\hline & 0.00 & 0.05 & 0.10 & 0.15 & 0.20 & 0.25 & 0.30 & 0.35 & 0.40 & 0.45 & $\mathbf{0 . 5 0}$ \\
\hline 0.0 & 0.00 & 0.00 & 0.00 & 0.83 & 0.95 & 0.95 & 0.95 & 0.95 & 0.95 & 0.95 & 0.95 \\
\hline 0.2 & 0.00 & 0.00 & 0.00 & 0.83 & 0.95 & 0.95 & 0.95 & 0.95 & 0.95 & 0.95 & 0.95 \\
\hline 0.4 & 0.00 & 0.00 & 0.00 & 0.82 & 0.92 & 0.93 & 0.94 & 0.95 & 0.95 & 0.95 & 0.95 \\
\hline 0.6 & 0.00 & 0.00 & 0.00 & 0.74 & 0.82 & 0.83 & 0.86 & 0.88 & 0.89 & 0.92 & 0.92 \\
\hline 0.8 & 0.00 & 0.00 & 0.00 & 0.67 & 0.73 & 0.74 & 0.77 & 0.79 & 0.81 & 0.83 & 0.85 \\
\hline
\end{tabular}




\begin{tabular}{|c|c|c|c|c|c|c|c|c|c|c|c|}
\hline \multicolumn{12}{|c|}{$\begin{array}{l}\text { 9.H. Percentage of firms preferring Equity }+ \text { Acc } \\
\qquad \text { rate }=30 \%\end{array}$} \\
\hline \multirow{2}{*}{ elusion } & \multicolumn{11}{|c|}{ return on investment } \\
\hline & 0.00 & 0.05 & 0.10 & 0.15 & 0.20 & 0.25 & 0.30 & 0.35 & 0.40 & 0.45 & 0.50 \\
\hline 0.0 & 0.95 & 0.95 & 0.95 & 0.95 & 0.95 & 0.95 & 0.83 & 0.60 & 0.24 & 0.12 & 0.00 \\
\hline 0.2 & 0.95 & 0.95 & 0.95 & 0.95 & 0.95 & 0.95 & 0.83 & 0.60 & 0.24 & 0.12 & 0.00 \\
\hline 0.4 & 0.87 & 0.87 & 0.88 & 0.89 & 0.89 & 0.89 & 0.78 & 0.55 & 0.19 & 0.09 & 0.00 \\
\hline 0.6 & 0.78 & 0.79 & 0.79 & 0.80 & 0.80 & 0.81 & 0.70 & 0.46 & 0.13 & 0.06 & 0.00 \\
\hline 0.8 & 0.71 & 0.71 & 0.71 & 0.73 & 0.73 & 0.73 & 0.62 & 0.39 & 0.10 & 0.05 & 0.00 \\
\hline \multicolumn{12}{|c|}{$\begin{array}{l}\text { 9.I. Percentage of firms preferring Equity + Semi-integrated System, discount } \\
\qquad \text { rate }=30 \%\end{array}$} \\
\hline \multirow{2}{*}{ elusion } & \multicolumn{11}{|c|}{ return on investment } \\
\hline & 0.00 & 0.05 & 0.10 & 0.15 & 0.20 & 0.25 & 0.30 & 0.35 & 0.40 & 0.45 & 0.50 \\
\hline 0.0 & 0.00 & 0.00 & 0.00 & 0.00 & 0.00 & 0.00 & 0.00 & 0.00 & 0.00 & 0.00 & 0.00 \\
\hline 0.2 & 0.01 & 0.01 & 0.00 & 0.00 & 0.00 & 0.00 & 0.00 & 0.00 & 0.00 & 0.00 & 0.00 \\
\hline 0.4 & 0.08 & 0.08 & 0.08 & 0.07 & 0.07 & 0.06 & 0.05 & 0.05 & 0.05 & 0.03 & 0.02 \\
\hline 0.6 & 0.17 & 0.16 & 0.16 & 0.15 & 0.15 & 0.14 & 0.13 & 0.13 & 0.13 & 0.11 & 0.09 \\
\hline 0.8 & 0.24 & 0.24 & 0.24 & 0.23 & 0.23 & 0.22 & 0.21 & 0.21 & 0.20 & 0.17 & 0.17 \\
\hline \multicolumn{12}{|c|}{$\begin{array}{l}\text { 9.J. Percentage of firms preferring debt, discount } \\
\qquad \text { rate }=30 \%\end{array}$} \\
\hline \multirow{2}{*}{ elusion } & \multicolumn{11}{|c|}{ return on investment } \\
\hline & 0.00 & 0.05 & 0.10 & 0.15 & 0.20 & 0.25 & 0.30 & 0.35 & 0.40 & 0.45 & 0.50 \\
\hline 0.0 & 0.00 & 0.00 & 0.00 & 0.00 & 0.00 & 0.00 & 0.00 & 0.36 & 0.60 & 0.83 & 0.95 \\
\hline 0.2 & 0.00 & 0.00 & 0.00 & 0.00 & 0.00 & 0.00 & 0.00 & 0.36 & 0.60 & 0.83 & 0.95 \\
\hline 0.4 & 0.00 & 0.00 & 0.00 & 0.00 & 0.00 & 0.00 & 0.00 & 0.36 & 0.60 & 0.83 & 0.93 \\
\hline 0.6 & 0.00 & 0.00 & 0.00 & 0.00 & 0.00 & 0.00 & 0.00 & 0.36 & 0.60 & 0.78 & 0.86 \\
\hline 0.8 & 0.00 & 0.00 & 0.00 & 0.00 & 0.00 & 0.00 & 0.00 & 0.36 & 0.58 & 0.73 & 0.79 \\
\hline
\end{tabular}


Post-Reform, Small Firms

\begin{tabular}{|c|c|c|c|c|c|c|c|c|c|c|c|}
\hline \multicolumn{12}{|c|}{$\begin{array}{l}\text { 9.K. Percentage of firms preferring Equity + Accr } \\
\qquad \text { rate }=10 \%\end{array}$} \\
\hline \multirow{2}{*}{ elusion } & \multicolumn{11}{|c|}{ return on investment } \\
\hline & 0.00 & 0.05 & 0.10 & 0.15 & 0.20 & 0.25 & 0.30 & 0.35 & 0.40 & 0.45 & 0.50 \\
\hline 0.0 & 0.95 & 0.95 & 0.83 & 0.61 & 0.40 & 0.21 & 0.07 & 0.01 & 0.00 & 0.00 & 0.00 \\
\hline 0.2 & 0.95 & 0.95 & 0.83 & 0.77 & 0.65 & 0.55 & 0.47 & 0.38 & 0.31 & 0.24 & 0.17 \\
\hline 0.4 & 0.90 & 0.92 & 0.80 & 0.81 & 0.72 & 0.65 & 0.61 & 0.54 & 0.49 & 0.43 & 0.38 \\
\hline 0.6 & 0.82 & 0.83 & 0.73 & 0.74 & 0.70 & 0.65 & 0.61 & 0.59 & 0.54 & 0.50 & 0.47 \\
\hline 0.8 & 0.76 & 0.76 & 0.67 & 0.67 & 0.68 & 0.62 & 0.58 & 0.57 & 0.54 & 0.51 & 0.48 \\
\hline \multicolumn{12}{|c|}{$\begin{array}{l}\text { 9.L. Percentage of firms preferring Equity + Semi-integrated System, discount } \\
\qquad \text { rate }=10 \%\end{array}$} \\
\hline \multirow{2}{*}{ elusion } & \multicolumn{11}{|c|}{ return on investment } \\
\hline & 0.00 & 0.05 & 0.10 & 0.15 & 0.20 & 0.25 & 0.30 & 0.35 & 0.40 & 0.45 & 0.50 \\
\hline 0.0 & 0.0 & 0.0 & 0.0 & 0.0 & 0.0 & 0.0 & 0.0 & 0.0 & 0.0 & 0.0 & 0.0 \\
\hline 0.2 & 0.0 & 0.0 & 0.0 & 0.0 & 0.0 & 0.0 & 0.0 & 0.0 & 0.0 & 0.0 & 0.0 \\
\hline 0.4 & 0.05 & 0.04 & 0.04 & 0.02 & 0.01 & 0.01 & 0.01 & 0.00 & 0.00 & 0.00 & 0.00 \\
\hline 0.6 & 0.13 & 0.12 & 0.11 & 0.09 & 0.08 & 0.07 & 0.07 & 0.05 & 0.04 & 0.04 & 0.03 \\
\hline 0.8 & 0.20 & 0.19 & 0.17 & 0.16 & 0.15 & 0.14 & 0.13 & 0.11 & 0.10 & 0.10 & 0.08 \\
\hline \multicolumn{12}{|c|}{$\begin{array}{l}\text { 9.M. Percentage of firms preferring debt, discount } \\
\text { rate }=10 \%\end{array}$} \\
\hline \multirow{2}{*}{ elusion } & \multicolumn{11}{|c|}{ return on investment } \\
\hline & 0.00 & 0.05 & 0.10 & 0.15 & 0.20 & 0.25 & 0.30 & 0.35 & 0.40 & 0.45 & 0.50 \\
\hline 0.0 & 0.00 & 0.00 & 0.00 & 0.34 & 0.55 & 0.74 & 0.88 & 0.94 & 0.95 & 0.95 & 0.95 \\
\hline 0.2 & 0.00 & 0.00 & 0.00 & 0.18 & 0.29 & 0.40 & 0.48 & 0.57 & 0.64 & 0.71 & 0.78 \\
\hline 0.4 & 0.00 & 0.00 & 0.00 & 0.12 & 0.22 & 0.29 & 0.34 & 0.41 & 0.46 & 0.52 & 0.57 \\
\hline 0.6 & 0.00 & 0.00 & 0.00 & 0.12 & 0.17 & 0.23 & 0.28 & 0.32 & 0.37 & 0.42 & 0.45 \\
\hline 0.8 & 0.00 & 0.00 & 0.00 & 0.12 & 0.12 & 0.20 & 0.24 & 0.27 & 0.31 & 0.34 & 0.39 \\
\hline
\end{tabular}




\begin{tabular}{|c|c|c|c|c|c|c|c|c|c|c|c|}
\hline \multicolumn{12}{|c|}{$\begin{array}{l}\text { 9.N. Percentage of firms preferring Equity + Accrual System, discount } \\
\text { rate }=30 \%\end{array}$} \\
\hline \multirow{2}{*}{ elusion } & \multicolumn{11}{|c|}{ return on investment } \\
\hline & 0.00 & 0.05 & 0.10 & 0.15 & 0.20 & 0.25 & 0.30 & 0.35 & 0.40 & 0.45 & 0.50 \\
\hline 0.0 & 0.95 & 0.95 & 0.95 & 0.95 & 0.95 & 0.95 & 0.83 & 0.82 & 0.71 & 0.61 & 0.53 \\
\hline 0.2 & 0.95 & 0.95 & 0.95 & 0.95 & 0.95 & 0.95 & 0.83 & 0.83 & 0.74 & 0.71 & 0.64 \\
\hline 0.4 & 0.90 & 0.90 & 0.92 & 0.92 & 0.93 & 0.93 & 0.82 & 0.82 & 0.80 & 0.73 & 0.70 \\
\hline 0.6 & 0.84 & 0.84 & 0.86 & 0.86 & 0.87 & 0.89 & 0.77 & 0.78 & 0.79 & 0.73 & 0.69 \\
\hline 0.8 & 0.78 & 0.79 & 0.79 & 0.81 & 0.82 & 0.82 & 0.71 & 0.73 & 0.73 & 0.71 & 0.67 \\
\hline \multicolumn{12}{|c|}{$\begin{array}{l}\text { 9.0. Percentage of firms preferring Equity + Semi-integrated System, discount } \\
\qquad \text { rate }=30 \%\end{array}$} \\
\hline \multirow{2}{*}{ elusion } & \multicolumn{11}{|c|}{ return on investment } \\
\hline & 0.00 & 0.05 & 0.10 & 0.15 & 0.20 & 0.25 & $\mathbf{0 . 3 0}$ & 0.35 & 0.40 & 0.45 & 0.50 \\
\hline 0.0 & 0.00 & 0.00 & 0.00 & 0.00 & 0.00 & 0.00 & 0.00 & 0.00 & 0.00 & 0.00 & 0.00 \\
\hline 0.2 & 0.01 & 0.00 & 0.00 & 0.00 & 0.00 & 0.00 & 0.00 & 0.00 & 0.00 & 0.00 & 0.00 \\
\hline 0.4 & 0.05 & 0.05 & 0.04 & 0.04 & 0.02 & 0.02 & 0.01 & 0.01 & 0.01 & 0.00 & 0.00 \\
\hline 0.6 & 0.11 & 0.11 & 0.10 & 0.09 & 0.08 & 0.07 & 0.07 & 0.05 & 0.05 & 0.04 & 0.03 \\
\hline 0.8 & 0.17 & 0.16 & 0.16 & 0.14 & 0.14 & 0.13 & 0.12 & 0.11 & 0.10 & 0.10 & 0.08 \\
\hline \multicolumn{12}{|c|}{$\begin{array}{l}\text { 9.P. Percentage of firms preferring debt, discount } \\
\text { rate }=30 \%\end{array}$} \\
\hline \multirow{2}{*}{ elusion } & \multicolumn{11}{|c|}{ return on investment } \\
\hline & 0.00 & 0.05 & 0.10 & 0.15 & 0.20 & 0.25 & 0.30 & 0.35 & 0.40 & 0.45 & 0.50 \\
\hline 0.0 & 0.00 & 0.00 & 0.00 & 0.00 & 0.00 & 0.00 & 0.00 & 0.14 & 0.24 & 0.34 & 0.42 \\
\hline 0.2 & 0.00 & 0.00 & 0.00 & 0.00 & 0.00 & 0.00 & 0.00 & 0.12 & 0.20 & 0.24 & 0.32 \\
\hline 0.4 & 0.00 & 0.00 & 0.00 & 0.00 & 0.00 & 0.00 & 0.00 & 0.12 & 0.14 & 0.23 & 0.25 \\
\hline 0.6 & 0.00 & 0.00 & 0.00 & 0.00 & 0.00 & 0.00 & 0.00 & 0.12 & 0.12 & 0.18 & 0.23 \\
\hline 0.8 & 0.00 & 0.00 & 0.00 & 0.00 & 0.00 & 0.00 & 0.00 & 0.12 & 0.12 & 0.15 & 0.20 \\
\hline
\end{tabular}




\section{TABLE 10}

SIMULATION EXERCISES: CHOOSING BETWEEN DEBT AND EQUITY WHEN ACCRUAL REGIME IS NOT POSSIBLE MAXIMUM CASH FLOWS (IN PV TERMS), EXCLUDING CASES OF INDIFFERENCE

Post reform large firms

\begin{tabular}{|c|c|c|c|c|c|c|c|c|c|c|c|}
\hline \multicolumn{12}{|c|}{ 10.A. Percentage of firms preferring equity + semi integrated regime, discount $10 \%$} \\
\hline \multirow{2}{*}{ elusion } & \multicolumn{11}{|c|}{ return on investment } \\
\hline & $\mathbf{0 . 0 0}$ & 0.05 & 0.10 & 0.15 & 0.20 & 0.25 & 0.30 & 0.35 & 0.40 & 0.45 & 0.50 \\
\hline $\mathbf{0 . 0}$ & 0.00 & 0.00 & 0.00 & 0.00 & 0.00 & 0.00 & 0.00 & 0.00 & 0.00 & 0.00 & 0.00 \\
\hline 0.2 & 0.01 & 0.00 & 0.00 & 0.00 & 0.00 & 0.00 & 0.00 & 0.00 & 0.00 & 0.00 & 0.00 \\
\hline 0.4 & 0.14 & 0.10 & 0.08 & 0.05 & 0.04 & 0.02 & 0.01 & 0.00 & 0.00 & 0.00 & 0.00 \\
\hline 0.6 & 0.24 & 0.21 & 0.18 & 0.16 & 0.14 & 0.12 & 0.09 & 0.07 & 0.06 & 0.04 & 0.03 \\
\hline 0.8 & 0.33 & 0.30 & 0.27 & 0.24 & 0.23 & 0.21 & 0.18 & 0.17 & 0.14 & 0.13 & 0.10 \\
\hline \multicolumn{12}{|c|}{ 10.B. Percentage of firms preferring debt, discount $10 \%$} \\
\hline \multirow{2}{*}{ elusion } & \multicolumn{11}{|c|}{ return on investment } \\
\hline & 0.00 & 0.05 & 0.10 & 0.15 & 0.20 & 0.25 & 0.30 & 0.35 & 0.40 & 0.45 & 0.50 \\
\hline $\mathbf{0 . 0}$ & 1.00 & 1.00 & 1.00 & 1.00 & 1.00 & 1.00 & 1.00 & 1.00 & 1.00 & 1.00 & 1.00 \\
\hline 0.2 & 0.99 & 1.00 & 1.00 & 1.00 & 1.00 & 1.00 & 1.00 & 1.00 & 1.00 & 1.00 & 1.00 \\
\hline 0.4 & 0.86 & 0.90 & 0.92 & 0.95 & 0.96 & 0.98 & 0.99 & 1.00 & 1.00 & 1.00 & 1.00 \\
\hline 0.6 & 0.76 & 0.79 & 0.82 & 0.84 & 0.86 & 0.88 & 0.91 & 0.93 & 0.94 & 0.96 & 0.97 \\
\hline 0.8 & 0.67 & 0.70 & 0.73 & 0.76 & 0.77 & 0.79 & 0.82 & 0.83 & 0.86 & 0.88 & 0.90 \\
\hline \multicolumn{12}{|c|}{ 10.C. Percentage of firms preferring equity + semi integrated regime, discount $30 \%$} \\
\hline \multirow{2}{*}{ elusion } & \multicolumn{11}{|c|}{ return on investment } \\
\hline & 0.00 & $\mathbf{0 . 0 5}$ & 0.10 & 0.15 & 0.20 & 0.25 & 0.30 & 0.35 & 0.40 & 0.45 & 0.50 \\
\hline $\mathbf{0 . 0}$ & 0.01 & 0.00 & 0.00 & 0.00 & 0.00 & 0.00 & 0.00 & 0.00 & 0.00 & 0.00 & 0.00 \\
\hline 0.2 & 0.12 & 0.10 & 0.07 & 0.05 & 0.04 & 0.02 & 0.01 & 0.00 & 0.00 & 0.00 & 0.00 \\
\hline 0.4 & 0.23 & 0.20 & 0.18 & 0.14 & 0.13 & 0.10 & 0.08 & 0.07 & 0.05 & 0.03 & 0.02 \\
\hline 0.6 & 0.30 & 0.28 & 0.26 & 0.23 & 0.21 & 0.19 & 0.16 & 0.15 & 0.13 & 0.11 & 0.09 \\
\hline 0.8 & 0.38 & 0.33 & 0.32 & 0.30 & 0.28 & 0.26 & 0.23 & 0.22 & 0.20 & 0.17 & 0.17 \\
\hline
\end{tabular}




\begin{tabular}{|l|l|l|l|l|l|l|l|l|l|l|l|}
\hline \multirow{8}{*}{ elusion } & \multicolumn{10}{|c|}{ 10.D. Percentage of firms preferring debt, discount 30\% } \\
\cline { 2 - 10 } & $\mathbf{0 . 0 0}$ & $\mathbf{0 . 0 5}$ & $\mathbf{0 . 1 0}$ & $\mathbf{0 . 1 5}$ & $\mathbf{0 . 2 0}$ & $\mathbf{0 . 2 5}$ & $\mathbf{0 . 3 0}$ & $\mathbf{0 . 3 5}$ & $\mathbf{0 . 4 0}$ & $\mathbf{0 . 4 5}$ & $\mathbf{0 . 5 0}$ \\
\hline $\mathbf{0 . 0}$ & 0.99 & 1.00 & 1.00 & 1.00 & 1.00 & 1.00 & 1.00 & 1.00 & 1.00 & 1.00 & 1.00 \\
$\mathbf{0 . 2}$ & 0.88 & 0.90 & 0.93 & 0.95 & 0.96 & 0.98 & 0.99 & 1.00 & 1.00 & 1.00 & 1.00 \\
$\mathbf{0 . 4}$ & 0.77 & 0.80 & 0.82 & 0.86 & 0.88 & 0.90 & 0.92 & 0.93 & 0.95 & 0.97 & 0.98 \\
$\mathbf{0 . 6}$ & 0.70 & 0.72 & 0.74 & 0.77 & 0.79 & 0.81 & 0.84 & 0.85 & 0.87 & 0.89 & 0.91 \\
$\mathbf{0 . 8}$ & 0.63 & 0.67 & 0.68 & 0.70 & 0.72 & 0.74 & 0.77 & 0.78 & 0.80 & 0.83 & 0.83 \\
\hline
\end{tabular}

\section{Post-Reform, Small Firms}

10.E. Percentage of firms preferring equity + semi integrated regime, discount $10 \%$

\begin{tabular}{|c|c|c|c|c|c|c|c|c|c|c|c|}
\hline \multirow{2}{*}{ elusion } & \multicolumn{11}{|c|}{ return on investment } \\
\hline & 0.00 & 0.05 & 0.10 & 0.15 & 0.20 & 0.25 & 0.30 & 0.35 & 0.40 & 0.45 & 0.50 \\
\hline 0.0 & 0.00 & 0.00 & 0.00 & 0.00 & 0.00 & 0.00 & 0.00 & 0.00 & 0.00 & 0.00 & 0.00 \\
\hline 0.2 & 0.14 & 0.11 & 0.08 & 0.05 & 0.04 & 0.02 & 0.01 & 0.00 & 0.00 & 0.00 & 0.00 \\
\hline 0.4 & 0.27 & 0.24 & 0.22 & 0.18 & 0.16 & 0.14 & 0.12 & 0.10 & 0.08 & 0.07 & 0.05 \\
\hline 0.6 & 0.36 & 0.35 & 0.31 & 0.29 & 0.26 & 0.24 & 0.21 & 0.20 & 0.18 & 0.17 & 0.14 \\
\hline 0.8 & 0.42 & 0.40 & 0.39 & 0.37 & 0.34 & 0.32 & 0.30 & 0.29 & 0.26 & 0.24 & 0.23 \\
\hline \multicolumn{12}{|c|}{ 10.F. Percentage of firms preferring debt, discount $10 \%$} \\
\hline \multirow{2}{*}{ elusion } & \multicolumn{11}{|c|}{ return on investment } \\
\hline & 0.00 & 0.05 & 0.10 & 0.15 & 0.20 & 0.25 & 0.30 & 0.35 & 0.40 & 0.45 & 0.50 \\
\hline 0.0 & 1.00 & 1.00 & 1.00 & 1.00 & 1.00 & 1.00 & 1.00 & 1.00 & 1.00 & 1.00 & 1.00 \\
\hline 0.2 & 0.86 & 0.89 & 0.92 & 0.95 & 0.96 & 0.98 & 0.99 & 1.00 & 1.00 & 1.00 & 1.00 \\
\hline 0.4 & 0.73 & 0.76 & 0.78 & 0.82 & 0.84 & 0.86 & 0.88 & 0.90 & 0.92 & 0.93 & 0.95 \\
\hline 0.6 & 0.64 & 0.65 & 0.69 & 0.71 & 0.74 & 0.76 & 0.79 & 0.80 & 0.82 & 0.83 & 0.86 \\
\hline 0.8 & 0.58 & 0.60 & 0.61 & 0.63 & 0.66 & 0.68 & 0.70 & 0.71 & 0.74 & 0.76 & 0.77 \\
\hline
\end{tabular}


10.G. Percentage of firms preferring equity + semi integrated regime, discount $30 \%$

\begin{tabular}{|l|l|l|l|l|l|l|l|l|l|l|l|}
\hline \multirow{2}{*}{ elusion } & \multicolumn{10}{|c|}{ return on investment } \\
\cline { 2 - 11 } & $\mathbf{0 . 0 0}$ & $\mathbf{0 . 0 5}$ & $\mathbf{0 . 1 0}$ & $\mathbf{0 . 1 5}$ & $\mathbf{0 . 2 0}$ & $\mathbf{0 . 2 5}$ & $\mathbf{0 . 3 0}$ & $\mathbf{0 . 3 5}$ & $\mathbf{0 . 4 0}$ & $\mathbf{0 . 4 5}$ & $\mathbf{0 . 5 0}$ \\
$\mathbf{0 . 0}$ & 0.14 & 0.11 & 0.08 & 0.05 & 0.04 & 0.02 & 0.01 & 0.00 & 0.00 & 0.00 & 0.00 \\
$\mathbf{0 . 2}$ & 0.27 & 0.24 & 0.21 & 0.18 & 0.16 & 0.13 & 0.12 & 0.10 & 0.08 & 0.07 & 0.05 \\
$\mathbf{0 . 4}$ & 0.36 & 0.33 & 0.31 & 0.29 & 0.26 & 0.24 & 0.21 & 0.20 & 0.18 & 0.17 & 0.14 \\
$\mathbf{0 . 6}$ & 0.42 & 0.40 & 0.37 & 0.36 & 0.34 & 0.32 & 0.30 & 0.27 & 0.26 & 0.23 & 0.23 \\
$\mathbf{0 . 8}$ & 0.46 & 0.45 & 0.43 & 0.40 & 0.39 & 0.38 & 0.35 & 0.34 & 0.32 & 0.30 & 0.29 \\
\hline
\end{tabular}

10.H. Percentage of firms preferring debt, discount $30 \%$

\begin{tabular}{|c|c|c|c|c|c|c|c|c|c|c|c|}
\hline \multirow{2}{*}{ elusion } & \multicolumn{10}{|c|}{ return on investment } \\
\cline { 2 - 11 } & $\mathbf{0 . 0 0}$ & $\mathbf{0 . 0 5}$ & $\mathbf{0 . 1 0}$ & $\mathbf{0 . 1 5}$ & $\mathbf{0 . 2 0}$ & $\mathbf{0 . 2 5}$ & $\mathbf{0 . 3 0}$ & $\mathbf{0 . 3 5}$ & $\mathbf{0 . 4 0}$ & $\mathbf{0 . 4 5}$ & $\mathbf{0 . 5 0}$ \\
\hline $\mathbf{0 . 0}$ & 0.86 & 0.89 & 0.92 & 0.95 & 0.96 & 0.98 & 0.99 & 1.00 & 1.00 & 1.00 & 1.00 \\
$\mathbf{0 . 2}$ & 0.73 & 0.76 & 0.79 & 0.82 & 0.84 & 0.87 & 0.88 & 0.90 & 0.92 & 0.93 & 0.95 \\
$\mathbf{0 . 4}$ & 0.64 & 0.67 & 0.69 & 0.71 & 0.74 & 0.76 & 0.79 & 0.80 & 0.82 & 0.83 & 0.86 \\
$\mathbf{0 . 6}$ & 0.58 & 0.60 & 0.63 & 0.64 & 0.66 & 0.68 & 0.70 & 0.73 & 0.74 & 0.77 & 0.77 \\
$\mathbf{0 . 8}$ & 0.54 & 0.55 & 0.57 & 0.60 & 0.61 & 0.63 & 0.65 & 0.66 & 0.68 & 0.70 & 0.71 \\
\hline
\end{tabular}

